\title{
Catostylus tagi (Class: Scyphozoa, Order: Discomedusae, Suborder: Rhizostomida, Family: Catostylidae) life cycle and first insight into its ecology
}

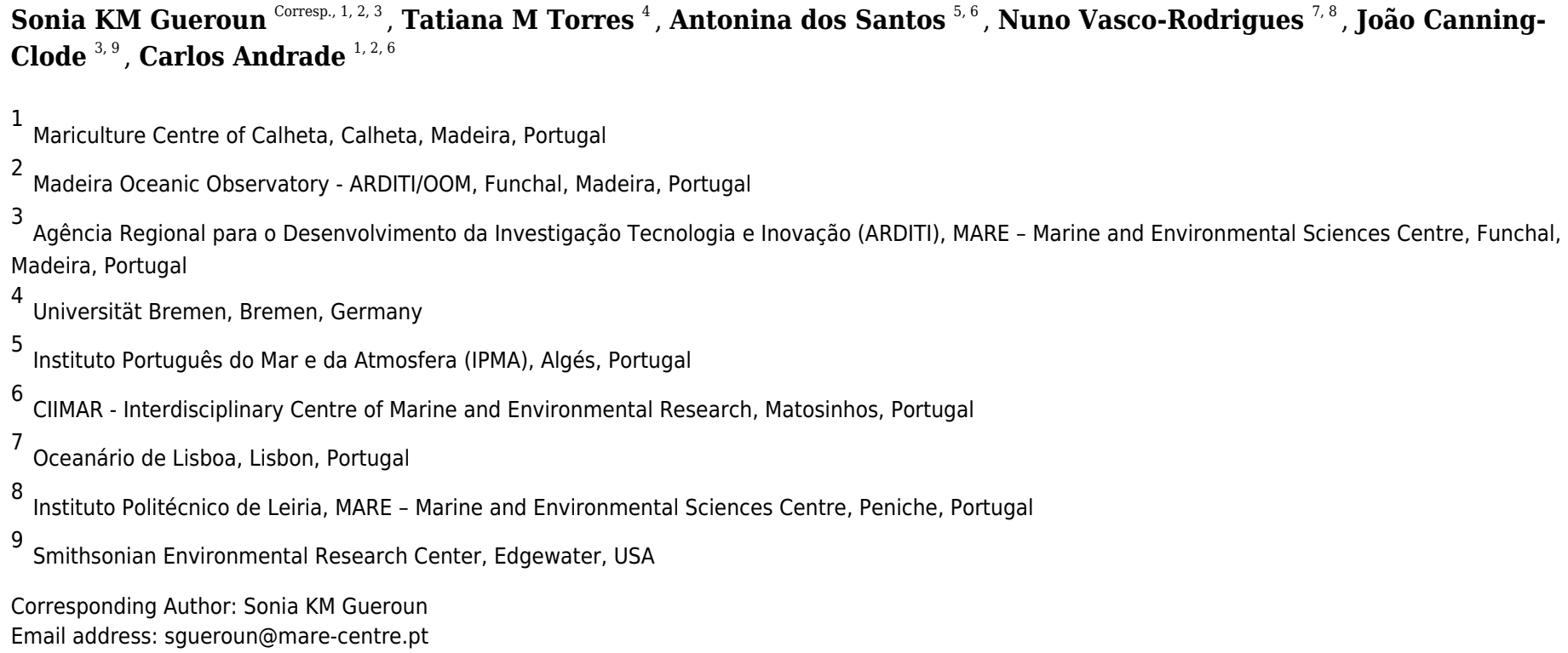

Jellyfish proliferations, which are conspicuous and natural events, cause blooms that may lead to severe consequences for anthropogenic activities and ecosystem structure and functioning. Although research during the last decade has focused on factors influencing the different jellyfish life stages, few species currently have their full life cycle known. In this context, we describe for the first time the developmental stages in the life cycle of Catostylus tagi, from planula to young medusa, reared in the laboratory. The species displays the typical Rhizostomida metagenetic life cycle. Mature scyphistomae display 16 tentacles and a total body length of $1.5 \pm 0.2 \mathrm{~mm}$. Only podocyst production and strobilation were observed. Strobilation, occurring continuously under laboratory conditions, was mainly polydisc. The eight-rayed typical ephyrae, with a total body diameter of $2.4 \pm 0.4 \mathrm{~mm}$ at detachment, showed development typical of the Rhizostomida. As a first step in studying this species' ecology, we also present preliminary assessments of: (i) the influence of different temperature and salinity regimes on planulae survival, settlement and metamorphosis and (ii) the effect of temperature and diet on asexual reproduction. The results showed a high tolerance of planulae to a wide range of salinities (15 to $25 \%$ ), while polyp development was significantly faster at higher temperature $\left(20-25^{\circ} \mathrm{C}\right.$ ). Strobilation onset was $2-3$ times faster at $20^{\circ} \mathrm{C}$ (10.6 \pm 5.4 to $15 \pm$ 6.6 day at various tested diet) than at $15^{\circ} \mathrm{C}(32.2 \pm 3$ day). Feeding was a key factor as 
unfed polyps never underwent strobilation during the trial. Finally, we present the spatial and seasonal distribution of $C$. tagi in the Tagus estuary (Portugal) in 2019, showing its occurrence throughout the year (except in April), with most observations recorded on the northern shoreline. As C. tagi shows the ability to form blooms and a wide tolerance for temperature and salinity (for planulae and medusae stage), it is essential to understand its life cycle. 
1 Catostylus tagi (Class: Scyphozoa, Order: Discomedusae, Suborder: Rhizostomida, Family:

2 Catostylidae) life cycle and first insight into its ecology

3 Sonia KM Gueroun ${ }^{1,2,3}$, Tatiana M Torres ${ }^{4}$, Antonina dos Santos ${ }^{5,6}$, Nuno Vasco-Rodrigues ${ }^{7,8}$,

4 João Canning-Clode ${ }^{1,9}$, Carlos Andrade ${ }^{2,3,6}$

$6 \quad{ }^{1}$ MARE - Marine and Environmental Sciences Centre, Agência Regional para o

7 Desenvolvimento da Investigação Tecnologia e Inovação (ARDITI), Edifício Madeira

8 Tecnopolo, Piso 0, Caminho da Penteada, 9020-105, Funchal, Madeira, Portugal

92 Mariculture Centre of Calheta, Madeira, Portugal

$10{ }^{3}$ Madeira Oceanic Observatory - ARDITI/OOM, Funchal, Madeira, Portugal

$11{ }^{4}$ Universität Bremen, Bremen, Germany

125 Instituto Português do Mar e da Atmosfera (IPMA), Av. Alfredo Magalhães Ramalho, 6,

13 1495-165 Algés, Portugal

$14{ }^{6}$ CIIMAR (Interdisciplinary Centre of Marine and Environmental Research), Terminal de

15 Cruzeiros do Porto de Leixões, Matosinhos, Portugal

$16{ }^{7}$ MARE - Marine and Environmental Sciences Centre, ESTM, Instituto Politécnico de

17 Leiria, Peniche, Portugal

$18{ }^{8}$ Oceanário de Lisboa. Esplanada D. Carlos I, 1990-005 Lisbon, Portugal

$19{ }^{9}$ Smithsonian Environmental Research Center, 647 Contees Wharf Road, Edgewater, MD

20 21037, USA

22 Corresponding author:

23 Sonia KM Gueroun

24 ARDITI, Edifício Madeira Tecnopolo, Piso 0, Caminho da Penteada, 9020-105, Funchal,

25 Madeira, Portugal

26 Email address: sgueroun@mare-centre.pt

27

28

29 
30 Abstract

31 Jellyfish proliferations, which are conspicuous and natural events, cause blooms that may lead to

32 severe consequences for anthropogenic activities and ecosystem structure and functioning.

33 Although research during the last decade has focused on factors influencing the different

34 jellyfish life stages, few species currently have their full life cycle known.

35 In this context, we describe for the first time the developmental stages in the life cycle of

36 Catostylus tagi, from planula to young medusa, reared in the laboratory. The species displays the

37 typical Rhizostomida metagenetic life cycle. Mature scyphistomae display 16 tentacles and a

38 total body length of $1.5 \pm 0.2 \mathrm{~mm}$. Only podocyst production and strobilation were observed.

39 Strobilation, occurring continuously under laboratory conditions, was mainly polydisc. The

40 eight-rayed typical ephyrae, with a total body diameter of $2.4 \pm 0.4 \mathrm{~mm}$ at detachment, showed

41 development typical of the Rhizostomida. As a first step in studying this species' ecology, we

42 also present preliminary assessments of: (i) the influence of different temperature and salinity regimes on planulae survival, settlement and metamorphosis and (ii) the effect of temperature and diet on asexual reproduction. The results showed a high tolerance of planulae to a wide range of salinities (15 to 25\%o), while polyp development was significantly faster at higher temperature $\left(20-25^{\circ} \mathrm{C}\right)$. Strobilation onset was $2-3$ times faster at $20^{\circ} \mathrm{C}(10.6 \pm 5.4$ to $15 \pm 6.6$ day at various tested diet) than at $15^{\circ} \mathrm{C}(32.2 \pm 3$ day). Feeding was a key factor as unfed polyps never underwent strobilation during the trial. Finally, we present the spatial and seasonal distribution of $C$. tagi in the Tagus estuary (Portugal) in 2019, showing its occurrence throughout the year (except in April), with most observations recorded on the northern shoreline. As C. tagi shows the ability to form blooms and a wide tolerance for temperature and salinity (for planulae and medusae stage), it is essential to understand its life cycle.

Keywords: Catostylidae, planula, polyp, ephyra, gastric system, salinity, Tagus estuary, temperature, diet, Atlantic Ocean 


\section{Introduction}

60 In recent decades, jellyfish have attracted much attention due to intense blooming events in coastal waters; such outbreaks often have negative repercussions on human activities (e.g., fisheries, aquaculture, tourism and power plants) and the structure and function of ecosystem (reviewed in Purcell et al., 2007; Pitt et al., 2009). Nonetheless, no common consensus has been reached on whether jellyfish are actually increasing globally (Condon et al., 2012) or regarding the implications of various anthropogenic causes triggering these gelatinous organisms to proliferate (Sanz-Martín et al., 2016).

With some exceptions (e.g., Pelagia noctiluca, Rottini Sandrini and Avian, 1983), Scyphozoan species are meroplanktonic with a bipartite life cycle. The pelagic medusa stage typically reproduces sexually, producing a free-swimming planula. After the planula attaches to a substrate, it grows into a sessile polyp. The polyp reproduces asexually through various budding modes (e.g., lateral budding, budding from stolon, motile bud-like tissue particles), podocysts and via strobilation (Arai, 1997). Environmental factors (e.g. temperature, prey supply) can affect both the sessile stage (e.g., asexual reproduction timing and intensity) (Yongze et al., 2016) and the pelagic stage (e.g., somatic growth and sexual maturation) (Pitt and Kingsford, 2000) of these species, making the study of both phases essential to scyphozoan biology. Understanding the influence of environmental factors on each life stage is crucial to better understanding the dynamics of the species, while identifying early stages is primordial to detecting potential blooms. Paradoxically, the complete life cycle of scyphozoans has been described for less than $25 \%$ of known species (Tronolone et al., 2002). Generally, only the adult stage of scyphozoans is known (Mills, 2001; Jarms and Morandini, 2019).

The Catostylus genus consists of ten valid species, occurring in temperate regions and subtropical and tropical regions (Jarms and Morandini, 2019). In the Atlantic, the genus is currently represented by three species: C. cruciatus (Lesson, 1830) in Brazil, C. tagi (Haeckel, 1869), whose distribution extends from the Atlantic coast of Europe (France, Spain and Portugal) to the West African coast (south of Congo) and C. tripterus (Haeckel, 1880), found off Equatorial Guinea. The distribution of $C$. tagi has been extended eastward since it was recorded as a non-indigenous species (NIS) in the Mediterranean Sea, in June 2010, in the Sicily Channel 
88 (Nastasi, 2010). Among the genus, only the life cycle of C. mosaicus has been investigated (Pitt, 89 2000).

90 Catostylus tagi is a common Scyphozoa in the Tagus estuary (Portugal), where juveniles and 91 adults have been observed (GelAvista citizen science project). No records of ephyrae or polyps 92 have been reported yet, and general information on this species' biology and ecology remain 93 scarce. To date, no studies the species'population dynamics, biology or ecology have ever been 94 published. Only the medusa stage of C. tagi has been described, while its complete life cycle 95 remains unknown. However, several studies on the biochemical properties of C. tagi have been 96 conducted; these studies have found edible species for human consumption (Amaral et al., 2018;

97 Raposo et al., 2018), as well as relevant collagen and antioxidant properties with potential as 98 new bio-resources for the cosmetics and food sectors (Calejo et al., 2009; Morais et al., 2009). Cattostylus tagi is moderately venomous (GelAvista, 2021) and is considered a harmless species in Portugal (Morais et al., 2009).

101 In the present study, we describe for the first time the complete life cycle of C. tagi based on

102 fertilisation trials conducted in the laboratory. Additionally, we conducted a preliminary

103 evaluation of the ecology of the species through assessments of the effect of: (i) temperature and

104 salinity on the planula stage (pre-settlement survival, settlement and metamorphosis) and (ii)

105 temperature and diet regimes on polyp asexual reproduction. Finally, we pioneer an overview of 106 the spatial and seasonal distribution of $C$. tagi along the Tagus estuary showing the potential of 107 the medusa stage to a broad range of temperature and salinity values.

108

\section{Materials and methods}

\section{Ethics statement}

111 The jellyfish C. tagi is not an endangered or protected species.

112

\section{Fertilisation}


114 In early October 2019, six medusae were collected from the Tagus estuary (Portugal), near the

115 Oceanário de Lisboa, and individually transferred to the laboratory within 30 mins in $15 \mathrm{~L}$

116 buckets. Specimens' sex and gonadal maturity were determined using a microscope. Of the six

117 individuals, two were males while four were females. Gonads were extracted from the two most

118 mature individuals, and gastric filaments and excess tissue removed. The female's and the male's

119 bell diameters were $39.5 \mathrm{~cm}$ and $43 \mathrm{~cm}$, respectively. The extracted gametes were mixed and

120 incubated for $48 \mathrm{~h}$ with constant aeration in $3 \mathrm{~L}$ containers containing ultraviolet-treated artificial

121 seawater (Red Sea's Premium salt $\left.{ }^{\circledR}\right)$ at a salinity of $35 \%$ and room temperature $\left(18^{\circ} \mathrm{C}\right)$. After 48

$122 \mathrm{~h}$, the planulae were collected by filtering the medium on gradient mesh $(200 \mu \mathrm{m}$ and $55 \mu \mathrm{m})$.

123 Plastic petri dishes, previously incubated for four days in natural seawater for biofilm

124 development, were used as substrates. The petri dishes were placed at mid-height in $500 \mathrm{ml}$ glass

125 bowls, thus allowing the planulae to settle on both sides of the substrate.

126 Culture maintenance

127 Planulae and polyps were incubated in artificial seawater (salinity $35 \%$ ) at $18{ }^{\circ} \mathrm{C}$ under a natural

128 light/dark cycle. Collected ephyrae were maintained in several $500 \mathrm{ml}$ jars. Once the metaephyra

129 stage was reached, individuals were transferred to a $60 \mathrm{~L}$ pseudo-Kreisel under the same

130 conditions (i.e., temperature, salinity and feeding regime).

131 Polyps were fed daily with rotifers (Brachionus plicatilis) during the first week, after which

132 newly hatched Artemia nauplii were added three times a week. Ephyrae and juveniles were fed

133 rotifers (four times a day), Artemia (three times a day) and mashed mussel (once a day). Nauplii

134 of AF Artemia Vietnam strain (small nauplii with high HUFA content, Inve Aquaculture $\mathrm{NV}^{\circledR}$ )

135 and enriched EG Salt Lake Artemia fransiscana (Inve Aquaculture NV ${ }^{\circledR}$, Baasrode, Belgium)

136 were used for ephyrae and juveniles, respectively. Every 2-3 days, a 50\% water exchange was

137 conducted.

138 Anatomical analysis

139 Two different Stereomicroscopes (Leica ${ }^{\circledR}$ SAPO and Leica ${ }^{\circledR}$ M165C) were used to describe

140 the various life stages, as well as to follow the development of the gastric system, manubrium,

141 and marginal lappets of the newly released ephyrae (stage 0 ) through to the metaephyra stage

142 (stage 7).

Peer] reviewing PDF | (2021:05:61520:1:1:NEW 2 Aug 2021) 
143 Measurements of the scyphistoma were taken following Straehler-Pohl et al. (2011): total body

144 length (TBL), calyx length (CL), hypostome length (HL), mouth disc diameter (MDD) and stalk

145 length (StL) (Fig. 1A). The following standard measurements were used for the young ephyrae

146 (Straehler-Pohl and Jarms, 2010): total body diameter (TBD), central disc diameter (CDD), total

147 marginal lappet length (TMLL), lappet stem length (LStL) and rhopalial lappet length (RLL)

148 (Fig. 1B). Relative body dimensions (\%) were calculated for scyphistomae (measurements

149 compared with body length, e.g., CL/TBL x 100, and calyx diameter, e.g., MDD/CL x 100) and

150 for ephyrae (measurements compared with body diameter, e.g., CDD/TBD x 100, and lappet

151 length, e.g., RLL/TMLL x 100). A total of 11 scyphistomae and 20 ephyrae from 5 strobilae

152 were measured.

153 The effect of temperature and salinity on planula development

154 Two orthogonal treatment sets were established with three temperatures $\left(15,20\right.$ and $\left.25^{\circ} \mathrm{C}\right)$ and

155 four different salinities (20, 25, 30 and 35\%o) reflecting conditions recorded in the Tagus area

156 (Gameiro et al., 2007; Rodrigues et al., 2017). Water was prepared by diluting artificial seawater

$157(35 \%)$ with distilled water. Each treatment was tested with eighteen replicates (planulae)

158 following the methods of Conley and Uye (2015) and Takao and Uye (2018). Thirty-six

159 polycarbonate culture plates, six-wells of $10 \mathrm{ml}$, were prepared (three plates per experimental

160 condition). Culture plates were filled with natural seawater four days prior to incubation in order

161 to allow for biofilm development. Acclimatation of the planulae to lower salinities $(30,25$, and

162 20\%o) was done in a step-wise fashion, soaking the planulae in water of each decreasing salinity

163 for 5 min until the target salinity was reached. Over six days, planulae were surveyed daily with

164 a stereomicroscope (Zeiss ${ }^{\circledR}$ Stemi 305). Life stages of the planulae were recorded in the

165 following manner: Dead; Stage 0: settled but no tentacles; Stage 1: 1-4 tentacles; Stage 2: 5-7

166 tentacles; Stage 3: 8-16 tentacles. None of the polyps were fed during this trial.

\section{The effect of temperature and feeding regimes on asexual reproduction}

168 Two orthogonal treatment sets were established with two temperatures $\left(15\right.$ and $\left.20^{\circ} \mathrm{C}\right)$ and three

169 feeding regimes, comprising groups being fed rotifers (Brachionus plicatilis; $\mathrm{R}_{\text {group}}$ ) or Artemia

170 sp. nauplii $\left(\mathrm{A}_{\text {group }}\right)$ or being unfed $\left(\mathrm{U}_{\text {group }}\right)$. Eighteen polyps were tested using of each treatment

171 combination. One polyp was placed per well into 6-well polycarbonate culture plates (three

172 plates per experimental condition) filled with $10 \mathrm{ml}$ of the artificial seawater (35\%). A water 
173 bath was used to maintain the designed temperatures. The photoperiod was maintained at $12 \mathrm{~h}$

174 light:12 h dark. After allowing the polyps one week to reattach and acclimate to the experimental

175 temperatures, newly hatched Artemia nauplii and B. plicatilis were fed in excess every two days.

176 After a feeding period of $1.5 \mathrm{~h}$, the wells were cleaned with swabs and uneaten food was

177 discarded, while the seawater was replaced with new water of the same temperature. This

178 feeding protocol provided saturating prey briefly, resulting in equal feeding in all treatments by

179 minimising enhanced feeding at warmer temperatures (Ma and Purcell, 2005). Specimens in the

180 unfed treatment never received food, although the water was exchanged similar to other

181 treatment groups. Polyps were examined daily for strobilation and ephyrae release and twice a

182 week for podocyst production. After enumeration, new ephyrae were removed but not the new

183 podocysts. The experiment lasted 33 days.

184 Several response variables were defined for analysis, comprising: the number of podocysts

185 produced by the polyps; the time from the beginning of the experiment to strobilation onset, i.e.,

186 the "pre-strobilation" period (pre-str); the time from the beginning of strobilation to the release

187 of the first ephyrae, i.e., the "bet-strobilation" period (bet-str); the time from the first release of

188 ephyrae to the release of the last ephyrae, i.e., the "strobilation period" (str) the number of

189 ephyrae produced for each strobilation event.

190

\section{Community science data}

192 This study presents data on C. tagi sightings from Tagus estuary for the year 2019 gathered in

193 the GelAvista Project's scope (gelavista.ipma.pt), mainly based on the GelAvista smartphone

194 App. The project is a citizen science program that provides information on jellyfish' presence in

195 Portugal through volunteer contributions of jellyfish sightings via the GelAvista smartphone

196 application, email address, and Facebook page. The collected data include GPS location, date,

197 and hour of sighting and the approximate number of specimens spotted. Species identification is

198 made through the examination of photographs or videos. A confidence level was assigned to all

199 reports, taking into account the veracity and sufficiency of the information received.

200

201 Statistical analysis

202 Since the measurements on the planulae consisted of repeated measures of binary outcomes, data

203 on the planktonic stage were assigned to durations from the experiment onset to settlement time 
204 (maximum of 160 hours) (Takao and Uye, 2018). The combined effect of temperature and

205 salinity on the planktonic duration was tested by two-way ANOVA followed by Tukey pair-wise 206 comparison. Data were square-root transformed to meet the residuals homogeneity assumption.

207 The pre-str data were analysed with generalised linear models for counts data. Due to excessive 208 zero in the data, a zero-inflated model was used (Zuur et al., 2009). When zero-inflated Poisson 209 model presented overdispersion, the model was corrected with the standard errors using a quasi-

210 GLM model and a third modelwas fitted with a negative binomial distribution. The best models 211 was selected based on the AIC and BIC values (Zuur et al., 2009).

212 Since only two combinations produced ephyrae, bet-str, str and ephyra released by strobilation

213 event were analysed with a $T$ or Wilcox ranking test depending on the variance homogeneity.

214 Data were analysed with the free R platform (version 3.0.2; R Development Core Team 2011)

215 using car (Fox and Weisberg, 2019) and glmmTMB (Brooks et al. 2017).

\section{Results}

217 Life cycle

218 Catostylus tagi displayed a typical metagenetic life cycle including scyphistoma and ephyra 219 phases (Fig. 2). The first polyps were observed approximately 96 hours after the planulae had 220 been added to the culture plates. The young polyps were translucent-white, cone-shaped, and 221 typically had four tentacles. Mature scyphistoma (Fig. 2A) had 16 tentacles in a single whorl 222 around a slightly sunken mouth disc. The four-lipped hypostome was short, $325 \pm 64 \mu \mathrm{m}(\approx 22 \%$ 223 TBL) and club-shaped. The calyx had an elongated cup shape. Scyphistoma colour varied from 224 white to pale orange depending on the feeding. Measurements of C. tagi mature scyphistoma are 225 summarized in table 1.

226 The scyphistoma proliferated asexually via podocysts (Fig. 2A); this proliferation was observed 227 starting as a periderm-enclosed podocyst. The podocysts were typically yellow or brown. A 228 finger-shaped stolon developed from the lower part of the stalk and attached to the substrate 229 allowing the scyphistoma to shift over. No other reproduction modalities, such as lateral budding 230 by stolon, lateral scyphistoma budding or pedalocysts were observed.

231 Both monodisc (producing one ephyra) and polydisk polydisc (producing multiple ephyrae) 232 strobilation were observed; monodisc strobilation was observed only once. At the first stage of 
233 strobilation, the calyx elongated and the first marginal lobe formed via constriction of the upper

234 part of the calyx (Fig. 2B); additional, marginal lobes progressively formed beneath this initial

235 one (Fig. 2C). The lappets and rhopalii appeared (Fig. 2D) and the scyphistoma tentacle

236 progressively achieve complete resorption. After release of the final ephyra, the residuum

237 developed new tentacles $(\mathrm{n}=16)$ and hypostome (Fig. 2E).

238 Newly released ephyrae (stage 0) typically had eight lappets with a pair of antler palm-like

239 rhopalial lappets with two to seven finger-like appendages (Fig. 2F). There was one rhopalium

240 per lappet. The tips of the rhopalial canals ended at the red-coloured rhopalium base; however,

241 the eight velar canals were either not developed or undistinguishable. The eight rhopalial canals

242 were slightly forked and with rounded points. There were one or two gastric filaments per

243 quadrant. The manubrium presented a four-lipped shape (Fig. 3A). Ephyrae exhibited colours

244 from dark pink to dark red. Measurements of newly released C. tagi ephyrae are summarized in 245 table 1.

246 As the timing of the developmental stages of ephyrae are affected by environmental conditions

247 (e.g., temperature, feeding), the stages are listed below in chronological order without designated 248 time period:

249 Stage 1 (Fig. 2G): The TBD doubled to $4.8 \pm 0.4 \mathrm{~mm}$. Eight rhombical velar canals appeared.

250 The velar canal thickened and the tips rounded-up. The first oral tentacles developed on the distal 251 ends of the manubrium (Fig. 3B).

252 Stage 2 (Fig. 2H): Lappet bulbs grew between the marginal lappets. The velar canals formed a 253 pair of branches midway. The manubrium started to split into four oral arms (Fig. 3C).

254 Stage 3 (Fig. 2I): The lappet bulbs developed into serrated velar lappets. The velar canals

255 lengthened centrifugally and the rhopalial canals formed a pair of side branches that grew

256 centrifugally toward the velar canals. The four oral arms divided to form eight arms (Fig. 3D).

257 Stage 4 (Fig. 2J): The side branches of the velar canals fused with the pair of side branches of the 258 rhopalial canals to form a primary ring canal. The velar lappets extended outward while their 259 serrations retracted.

260 Stage 5 (Fig. 2K): The velar lappets continued their extension outwards. The serrations on the 261 antler palm-like rhopalial lappets retracted. Two new canals grew on the velar canal, developing 
262 centripetally (tertiary canals) parallel to the radial canals, while two additional canals developed

263 horizontally toward the rhopalial canal.

264 Stage 6 (Fig. 2L): The midway-side branches of the velar canal fused with the radial velar canals

265 to form a secondary ring canal. The centripetal canal fused with the second ring and continued

266 growing centripetally. Below the second ring, the radial canal developed another set of side

267 branches to form the final ring canal. The velar lappet extremities extended until reaching the

268 rhopalial lappets yo complete the umbrella.

269 Stage 7 (Fig. 2M): The tips of the centripetally growing canals avoid the fusion, instead protruding

270 into the space between the last ring canal and the stomach. The floor and the roof of the canals

271 fused, forming woven "Inseln", constituting a mesh network of anastomosing canals.

272 Five months after ephyrae are released from the strobilae, juvenile C. tagi are fully developed

273 (Fig. 4).

274

275 Temperature and salinity effect on planulae development

276 Planulae of C. tagi showed relatively low mortality ( $\leq 20 \%)$, especially at $15^{\circ} \mathrm{C}$. No mortality 277 was observed at 30\%o salinity (Fig. 5). The first planulae settlement occurred within four to six

278 hours in all treatment combinations. The final settlement proportion varied from $53 \%\left(15^{\circ} \mathrm{C}\right.$ and $27925 \%$ ) to $100 \%\left(25^{\circ} \mathrm{C}\right.$ and 25 - 35\% $)$. The planktonic duration (Fig. 6, Table 2) was

280 significantly influenced by temperature $(p<0.001)$ and salinity $(p<0.01)$, however, no

281 interaction was detected $(p=0.31)$. Tukey post hoc testing revealed planula settlement to be

282 faster at higher temperatures $\left(25^{\circ} \mathrm{C}\right)$, while the planktonic stage duration was significantly

283 prolonged at $30 \%$ salinity when compared to $35 \%$.

284 No polyps with tentacles were observed at $15^{\circ} \mathrm{C}$, all salinities considered. Polyp development 285 was enhanced at higher temperatures, being optimal at $25^{\circ} \mathrm{C}$ for all salinities. Up to $54.2 \%$ of the 286 planulae developed into polyps under conditions of $25^{\circ} \mathrm{C}$ and $20 \%$. During the experiment, 287 polyps developed a maximum of eight tentacles, seen at the highest temperature $\left(25^{\circ} \mathrm{C}\right)$ with 288 lower salinities (20 and 25\%). Morphological deformities were not detected. 
291 Podocyst production, which varyied between $0.8 \pm 0.9$ and $1.7 \pm 1.5$ podocysts per scyphisotma, 292 was neither influenced by temperature $(p=0.21)$ nor by feeding regime $(p=0.3)$, with no 293 significant interaction detected $(p=0.17)$ (Fig. 7, Table 3).

294 At 20 and $15^{\circ} \mathrm{C}$, strobilation occurred only in three groups: $20^{\circ} \mathrm{C}-\mathrm{R}_{\text {group }}(61.1 \%), 20^{\circ} \mathrm{C}-\mathrm{A}_{\text {group }}$ $295(61.1 \%)$ and $15^{\circ} \mathrm{C}-\mathrm{A}_{\text {group }}(28 \%)$. Pre-str, which was significantly influenced by temperature and 296 diet, was shorter in the $20^{\circ} \mathrm{C}$ - $\mathrm{R}_{\text {group }}(11 \pm 4$ days $)$ and $20^{\circ} \mathrm{C}$ - $\mathrm{A}_{\text {group }}(15 \pm 7$ days $)$ than in the 15 $297{ }^{\circ} \mathrm{C}-\mathrm{A}_{\text {group }}(32 \pm 3$ days) (Table 2 , Table 3$)$.

298 Ephyrae release was only observed at $20^{\circ} \mathrm{C}$. The duration of bet-str $\left(\mathrm{R}_{\text {group }}: 5.7 \pm 1.4\right.$ days; $299 \mathrm{~A}_{\text {group }}: 5.6 \pm 2.6$ days) and the number of ephyrae produced by strobilation $\left(\mathrm{R}_{\text {group }}: 6.3 \pm 3.5\right.$; 300 A $_{\text {group }}: 6.9 \pm 3.9$ ) were not significantly affected by the diet (Table 2, Table 3). The strobilation 301 period was significantly shorter in the $\mathrm{R}_{\text {group }}\left(2.5 \pm 2.3\right.$ days) than in the $\mathrm{A}_{\text {group }}(26.4 \pm 3.9$ days)

302 (Table 2, Table 3). Twenty-seven per cent of the scyphistomae in the $20^{\circ} \mathrm{C}-\mathrm{R}_{\text {group }}$ were able to 303 perform new strobilation 10 to 16 days after ending the first strobilation. The number of ephyrae 304 produced by those scyphistomae did not change between the first $(4 \pm 1.7)$ and the second 305 strobilation $(3.7 \pm 0.6)$.

306

Seasonal distribution of Catostylus tagi adults in the Tagus estuary

308 During 2019, sightings of adult C. tagi were reported via the GelAvista smartphone App along

309 both margins of the Tagus estuary, from the inner bay and Cala do Norte to the estuary's

310 opening to the Atlantic Ocean (Fig. 8A). Sightings were recorded in all months of the year

311 except April (Fig. 8B). Many sightings ( $>5$ ) were recorded from September to February, a proxy

312 for a higher abundance of this species.

313

\section{Discussion}

315 This work represents the first complete description of the life cycle of C. tagi, including the first 316 insights into its ecology. We emphasise that baseline studies on important blooming species, such 317 as the current study, are a crucial aspect of understanding jellyfish fluctuations and their economic 318 impact. 
319 The jellyfish C. tagi displays a typical metagenetic life cycle for Rhizostomida, including a

320 benthic scyphistoma phase that reproduces asexually via strobilation, releasing ephyrae that grow 321 into pelagic medusae that reproduce sexually. Our observations of adult gonads from individuals

322 (18 medusae, six used in the present study) collected in the Tagus estuary (Portugal) for the

323 fertilisation showed the absence of planulae. Several scenarios may explain this absence; either

324 C. tagi, unlike C. mosaicus (Pitt, 2000) and some other Rhizostomida (Table 4), is a non-

325 brooding species or $C$. tagi sexual reproduction occurs later in the year than the present sampling

326 period. Additional studies on extended periods are necessary to clarify this issue.

327 Adult medusae of Catostylus tagi and C. mosaicus present multiple clear morphological

328 distinctions (Jarms and Morandini, 2019), such as in the umbrella (hemispherical and up to 35

$329 \mathrm{~cm}$ wide with coarse granulation for C. mosaicus while flattened hemispherical and up to $65 \mathrm{~cm}$

330 wide with fine granulation for C. tagi), the number of total marginal lappets (128 for C. mosaicus

331 and 80 C. tagi); the velar lappet shape (oval in C. mosaicus but triangular in C. tagi) or the

332 terminal portion of tapering filaments on the oral mouth and the purple margin on the umbrella

333 only seen in C. tagi. In contrast, distinguishing between earlier stages of these species is more of

334 a challenge (Table 4). Comparisons between both the polyps and ephyrae of $C$. tagi and $C$.

335 mosaicus showed very few differences between the species. Both ephyra species develop into an

336 8-rayed medusa with 16 antler palm-like rhopalial lappets and have similar body proportions

337 (Straehler-Pohl and Jarms, 2010). The main contrast between these two species lies in the velar

338 canal shape, which is rhombical in C. tagi and spade-like in C. mosaicus (Straehler-Pohl and

339 Jarms, 2010). These anatomic characteristics of C. tagi ephyra distinguish the species from the

340 other two Rhizostomatidae occurring in the same geographical area, Rhizostoma luteum

341 (rhombical shape velar canal and slightly forked rhopalial canal) (Kienberger et al., 2018) and

342 Rhizostoma octopus (flat rhombical shape velar canal and slightly forked rhopalial canal) (Holst

343 et al., 2007). Traditionally, the Discomedusae order was divided into two orders: the

344 Semaeostomeae and the Rhizostomeae, including the Kolpophorae (Cepheida) and the

345 Daktyliophorae (Rhizostomida) suborders. Recently, Jarms and Morandini (2019) proposed

346 distinguishing three suborders: Semaeostomeae, Cepheida and Rhizostomida. The distinction

347 between the Cepheida and Rhizostomida is based on development of the gastrovascular network;

348 gastric system develops centrifugally in the Cepheida and centripetally in the Rhizostomida

349 (Holst et al., 2007; Straehler-Phol, 2009). Catostylus tagi gastric development followed the same 
350 model of the previously described Rhizostomida such as Rhizostoma pulmo (Fuentes et al.,

351 2011) and Stomolophus sp.2 (Gómez-Salinas et al., 2021).

352 Scyphozoan species exhibit several propagation strategies, including various budding modes

353 (e.g., lateral budding, budding from the stolon and motile bud-like tissue particles) and podocysts

354 (Arai, 1997). These propagation strategies are species-specific. Some species adopt a mono-

355 mode, such as free-swimming planuloids in Phyllorhiza punctata (Rippingale and Kelly, 1995)

356 or podocysts in Rhopilema nomadica and R. luteum (Lotan et al., 1992; Kienberger et al., 2018).

357 In contrast, some species combine two or more strategies, as seen in Aurelia spp. (e.g., lateral

358 budding, lateral budding through stolons, reproduction from parts of stolons/stalks, motile bud-

359 like tissue particles and podocysts) (Schiariti et al., 2014). Unlike C. mosaicus, which combines

360 various strategies, including lateral polyp buds, podocysts, pedalocysts and longitudinal fission

361 (Pitt, 2000; Straehler-Pohl, 2009), C. tagi propagation seems to be limited to podocysts, at least

362 under the tested conditions. Moreover, podocysts production was not influenced by temperature

$363\left(15-20^{\circ} \mathrm{C}\right)$ nor feed regime (unfed, rotifer or Artemia). The reproductive strategy adopted by a

364 species of scyphozoan plays a significant role in the polyp reproduction rate (Schiariti et al.,

365 2014) and, consequently, the potential for medusae outbreaks. Among the various propagation

366 modes, podocysts present the lowest reproduction rate. Podocysts contain stored nutritional

367 reserves in carbohydrates, lipids, and proteins (Black, 1981; Chapman, 1968), which can remain

368 dormant for an extended period. Thein et al. (2012) found that Aurelia aurita s.1. podocysts were

369 able to survive for up to 3.2 years. Early studies speculated that podocysts represents an asexual

370 reproduction strategy induced by poor environmental conditions and protection against predators

371 (Cargo and Schultz, 1967). For instance, starvation or below food threshold conditions trigger

372 podocyst formation in Aurelia aurita s.1. (Han and Uye, 2010; Thein et al., 2012). However,

373 results in several other species have shown that podocyst formation is enhanced by increasing

374 food supply and temperature (Kawahara et al., 2013; Schiariti et al., 2014). This contrast is

375 related to the asexual reproduction mode (e.g., mono-mode or multi-mode) adopted by the

376 species. In mono-mode species (e.g., Lychnorhiza lucerna, R. pulmo, Rhopilema esculentum,

377 Nemopilema nomurai and Stomolophus meleagris) in which podocysts are the only form of

378 asexual polyp reproduction besides strobilation, increase in temperature and food supply enhance

379 podocyst production; meanwhile, these same factors boost budding and stolon production in

380 multi-mode species. Although C. tagi only produced podocysts during the present study, it would 
381 be premature to categorically consider $C$. tagi as a mono-mode species. More investigations will

382 be required with longer trials analysing a wider range in temperatures and the effect other

383 factors, such as salinity, oxygen and $\mathrm{pH}$.

384 In line with other Rhizostomida species (with the exception of $R$. luteum), polydisc was the 385 predominant strobilation type observed in C. tagi (Table 4). The first scyphistomae were 386 observed three days after fertilisation and strobilated approximately ten days later $\left(18^{\circ} \mathrm{C}, 35\right.$

387 \%). Strobilation onset, duration, and the number of ephyrae produced by polydisc scyphistoma 388 are influenced by environmental factors, such as temperature (Purcell et al., 2012) and food 389 supply (Wang et al., 2015). Other factors, such as age and size (Russell, 1970; Holst, 2012), are 390 intrinsic to scyphistoma. Under the various experimental conditions used to rear C. $\operatorname{tag} i$ in the 391 current study, strobilation onset was faster at higher temperatures and was triggered by the 392 availability of food (no strobilation in unfed scyphistoma). Surprisingly, while diet type can 393 affect the number of produced ephyrae (Purcell et al., 1999; Wang et al., 2015), C. tagi ephyrae 394 production was not influenced by diet type (rotifer or Artemia), indicating that both diets are 395 suitable.

396 Under the diverse conditions (temperature and diet) used in the present study, including

397 broodstock and the experiments, C. tagi scyphistomae underwent repeatedly strobilated twice a 398 month $\left(\geq 18^{\circ} \mathrm{C}\right)$, producing up to 15 ephyrae $(6.8 \pm 3.6)$; this ephyrae production exceeds 399 reported values for C. mosaicus of up to 5 ephyrae per strobilation (Pitt, 2000). However, it is 400 unknown whether the culture conditions of the previous $C$. mosaicus study were optimum for strobilation. C. tagi scyphistoma strobilated through a wide temperature range varying from 15 to $25^{\circ} \mathrm{C}$ (Gueroun, personal communication). This temperature range $\left(15-25^{\circ} \mathrm{C}\right)$ has been recorded in the Tagus (Gameiro et al., 2007), which may explain the continuous occurrence of $C$. tagi medusae in the estuary from May to March.

405

406

407

408

409

410
In the scyphozoan life cycle, the lecithotrophic and short-lived (around ten days) planula larval stage is undoubtedly the most vulnerable life stage. The recruitment of a new generation depends upon larvae pre-settlement survival, as well as their capacity to settle and metamorphose into the robust feeding polyp stage before their energy reserves run out. The Tagus estuary displays high spatial and temporal hydrographic fluctuations (Gameiro et al., 2007; Rodrigues et al., 2017). The data collected on C. tagi medusa presence in the Tagus estuary between 2016 and 2019

Peer] reviewing PDF | (2021:05:61520:1:1:NEW 2 Aug 2021) 
411 (Gelavista, 2019; present study) shows the occurrence of the species from May to March (2019),

412 suggesting a wide tolerance of the medusa stage to varying temperatures and salinities, similar to

413 previous observations in C. mosaicus (Loveridge et al., 2021). In our experiment, the

414 euryhalinity and eurythermal characteristics of the planula stage of C. tagi were confirmed, as

415 results demonstrated a low mortality rate and faster metamorphosis into polyps at higher

416 temperatures. The euryhalinity exhibited by C. tagi planulae might also be retained by polyps, as

417 the species-specific tolerance to low salinities was largely comparable for both planulae and

418 polyps in several estuarine and brackish water scyphozoan species, including Chrysaora

419 pacifica, N. nomurai, R. esculentum and Aurelia coerulea (Holst and Jarms, 2010; Conley and

420 Uye, 2015; Dong et al., 2015; Takao and Uye, 2018).

421 The timing and magnitude of scyphomedusae recruitment depends on numerous factors,

422 including the survial and settlement success of planulae, the abundance and rate of polyp

423 strobilation and the rate of ephyrae survival; notably. All of these factors are influenced by

424 various environemental conditions, mainly temperature, salinity and diet. Taking into account the

425 spatial-temporal distribution of C. tagi in the Tagus estuary (May to March), the wide

426 temperature and salinity tolerance of planulae, and the strobilation temperature range (15 to 25

$427{ }^{\circ} \mathrm{C}$ ), the possibility of several successive cohorts is suggested, as opposedto a longevity of 11

428 months in the medusa stage. The absence of medusae in April mayt be explained by a

429 recruitment cessation resulting from minimal strobilation or low ephyrae survival rates, during

430 the coolest months of November and December $\left(\leq 12^{\circ} \mathrm{C}\right)$. Strobilation cessations or slowdowns

431 during low temperature periods have been documented and have been attributed to diminished

432 abilities of polyps to feed or increased time required for strobilation (Widmer et al., 2016;

433 Purcell et al. 2012)

\section{Conclusion}

435 The present observations indicate a high tolerance and plasticity of the species, contributing to a

436 better understanding of the biology and ecology of C. tagi. The euryhaline and eurytherm

437 characteristics displayed by the planulae and reflected by the temporal and spatial distribution of

438 medusae in the Tagus estuary are advantageous for future C. tagi aquaculture, research and

439 production. Further studies must be conducted on the polyp and ephyra stages to determine

440 critical environmental factors affecting asexual reproduction and growth. Finally, studies such as 
441 the one we present here are essential for evaluating the response of $C$. tagi to climate change, as

442 well as predicting any temporal and geographic spreading of the species.

443

\section{Acknowledgements}

445 The authors are grateful to the Curator Núria Baylina and the aquarists' team (Raul Gouveia, 446 Catarina Barraca and Carlos Cunha) of the Oceanário de Lisboa for facilitating the sampling

447 inside the dock and for providing us space and the conditions within which we could conduct our 448 present research. The authors are also grateful to Susana Garrido from IPMA for the support and 449 the citizens participating in the Gelavista project. We thank the Editor and three Referees for 450 their constructive criticism and valuable observations that greatly strengthened the original 451 manuscript.

452

453 Funding: This work was supported by the project GoJelly_A gelatinous solution to plastic 454 pollution-funding from the European Union's Horizon 2020 research and innovation 455 programme under grant agreement No. 774499. This study also had the support of Fundação para 456 a Ciência e Tecnologia (FCT), through the strategic project [UIDB/04292/2020] granted to 457 MARE UI\&I. JCC is funded by national funds through FCT - Fundação para a Ciência e a 458 Tecnologia, I.P., under the Scientific Employment Stimulus - Institutional Call 459 [CEECINST/00098/2018]. This research was also supported by the GelAvista citizen Science 460 program under the Project PLANTROF Dinâmica do plâncton e transferência trófica:

461 Biodiversidade e ecologia do zooplankton de Portugal: Mar 2020_Programa Operacional Mar 4622020 Portaria N. 118/2016. There was no additional external funding received for this study.

\section{References}

465

466

467
Amaral L., Raposo A., Morais Z., Coimbra A. 2018. Jellyfish ingestion was safe for patients with crustaceans, cephalopods, and fish allergy. Asia Pacific allergy 8:e3. DOI: 10.5415/apallergy.2018.8.e3. 
468

469

470

471

472

473

474

475

476

477

478

479

480

481

482

483

484

485

486

487

488

489

490

491

492

493

494

495

496

497

498

499

500

Arai MN. 1997. A functional biology of Scyphozoa. London: Chapman \& Hall.

Black RE. 1981. Metabolism and ultrastructure of dormant podocysts of Chrysaora quinquecirrha (Scyphozoa). Journal of Experimental Zoology 218:175-182. DOI: 10.1002/jez.1402180210.

Brooks ME, Kristensen K, van Benthem KJ, Magnusson A, Berg CW, Nielsen A, Skaug HJ, Maechler M, Bolker BM. 2017. glmmTMB Balances Speed and Flexibility Among Packages for Zero-inflated Generalized Linear Mixed Modeling. The R Journal, 9(2), 378400

Calejo MT., Morais ZB., Fernandes AI. 2009. Isolation and biochemical characterisation of a novel collagen from Catostylus tagi. Journal of Biomaterials Science, Polymer Edition 20:2073-2087. DOI: 10.1163/156856208X399125.

Cargo DG., Schultz LP. 1967. Further observations on the biology of the sea nettle and jellyfishes in Chesapeake Bay. Chesapeake Science 8:209-220. DOI: 10.2307/1350339.

Chapman DM. 1968. Structure, histochemistry and formation of the podocyst and cuticule of Aurelia aurita. Journal of the Marine Biological Association of the UK 48:187-208.

Condon RH., Graham WM., Duarte CM., Pitt KA., Lucas CH., Haddock SHD., Sutherland KR., Robinson KL., Dawson MN., Decker MB., Mills CE., Purcell JE., Malej A., Mianzan H., Uye S., Gelcich S., Madin LP. 2012. Questioning the rise of gelatinous zooplankton in the world's oceans. BioScience 62:160-169. DOI: 10.1525/bio.2012.62.2.9.

Conley K., Uye S. 2015. Effects of hyposalinity on survival and settlement of moon jellyfish (Aurelia aurita) planulae. Journal of Experimental Marine Biology and Ecology 462:14-19. DOI: $10.1016 /$ j.jembe.2014.10.018.

Dong J., Sun M., Purcell JE., Chai Y., Zhao Y., Wang A. 2015. Effect of salinity and light intensity on somatic growth and podocyst production in polyps of the giant jellyfish Nemopilema nomurai (Scyphozoa: Rhizostomeae). Hydrobiologia 754:75-83. DOI: 10.1007/s10750-014-2087-y.

Feng S., Lin J., Sun S., Zhang F., Li C. 2018. Hyposalinity and incremental micro-zooplankton supply in early-developed Nemopilema nomurai polyp survival, growth , and podocyst reproduction. Marine Ecology Progress Series 591:117-128. DOI: 10.3354/meps12204.

Fox J., Weisberg S. 2019. An R Companion to Applied Regression. Thousand Oaks CA: Sage.

Gameiro C., Cartaxana P., Brotas V. 2007. Environmental drivers of phytoplankton distribution and composition in Tagus Estuary, Portugal. Estuarine, Coastal and Shelf Science 75:2134. DOI: $10.1016 /$ j.ecss.2007.05.014. 
501 Gómez-Salinas LC., López-Martínez J., Morandini AC. 2021. The young stages of the 502 Cannonball jellyfish (Stomolophus sp. 2) from the Central Gulf of California (Mexico). 503 Diversity 13:229. DOI: 10.3390/d13060229.

504

505

506

507

508

509

510

511

512

513

514

515

516

517

518

519

520

521

522

523

524

525

526

527

528

529

530

531

532
Han C-H., Uye S. 2010. Combined effects of food supply and temperature on asexual reproduction and somatic growth of polyps of the common jellyfish Aurelia aurita s.l. Plankton \& Benthos Research 5:98-105.

Holst S. 2012. Effects of climate warming on strobilation and ephyra production of North Sea scyphozoan jellyfish. Hydrobiologia 690:127-140. DOI: 10.1007/s10750-012-1043-y.

Holst S., Jarms G. 2010. Effects of low salinity on settlement and strobilation of scyphozoa (Cnidaria): Is the lion's mane Cyanea capillata (L.) able to reproduce in the brackish Baltic Sea? Hydrobiologia 645:53-68.

Holst S., Sötje I., Tiemann H., Jarms G. 2007. Life cycle of the rhizostome jellyfish Rhizostoma octopus (L.) (Scyphozoa, Rhizostomeae), with studies on cnidocysts and statoliths. Marine Biology 151:1695-1710. DOI: 10.1007/s00227-006-0594-8.

Jarms G., Morandini AC. 2019. World atlas of jellyfish. Dölling und Galitz Verlag.

Kienberger K., Riera-buch M., Scho AM., Bartsch V., Halbauer R., Prieto L. 2018. First description of the life cycle of the jellyfish Rhizostoma luteum (Scyphozoa: Rhizostomeae). PLoS ONE:1-24. DOI: 10.1371/journal.pone.0202093.

Lotan A., Ben-Hillel R., Loya Y. 1992. Life cycle of Rhopilema nomadica: a new immigrant scyphomedusan in the Mediterranean. Marine Biology 112:237-242.

Loveridge A., Pitt KA., Lucas CH., Warnken J. 2021. Extreme changes in salinity drive population dynamics of Catostylus mosaicus medusae in a modified estuary. Marine Environmental Research 168:105306. DOI: 10.1016/j.marenvres.2021.105306.

Ma X., Purcell JE. 2005. Temperature, salinity, and prey effects on polyp versus medusa bud production by the invasive hydrozoan Moerisia lyonsi. Marine Biology 147:225-234. DOI: 10.1007/s00227-004-1539-8.

Mills CE. 2001. Jellyfish blooms : are populations increasing globally in response to changing ocean conditions? Hydrobiologia 451:55-68.

Morais ZB., Pintao AM., Costa IM., Calejo MT., Bandarra NM., Abreu P. 2009. Composition and in vitro antioxidant effects of jellyfish Catostylus tagi from Sado estuary (SW Portugal). Journal of Aquatic Food Product Technology 18:90-107. DOI: 10.1080/10498850802581799. 
533

534

535

536

537

538

539

540

541

542

543

544

545

546

547

548

549

550

551

552

553

554

555

556

557

558

559

560

561

562

563

564

565

566

Nastasi A. 2010. Reported cases of algal and jellyfish blooms in the Mediterranean and Black Sea: an updated review. In: GFCM Worskshop on Algal and Jellyfish Blooms in the Mediterranean and Black Sea. $57 \mathrm{pp}$.

Pitt KA. 2000. Life history and settlement preferences of the edible jellyfish Catostylus mosaicus (Scyphozoa: Rhizostomeae). Marine Biology 136:269-279.

Pitt KA., Kingsford MJ. 2000. Reproductive biology of the edible jellyfish Catostylus mosaicus (Rhizostomeae). Marine Biology 137:791-799. DOI: 10.1007/s002270000399.

Pitt KA., Welsh DT., Condon RH. 2009. Influence of jellyfish blooms on carbon, nitrogen and phosphorus cycling and plankton production. Hydrobiologia 616:133-149.

Purcell JE., Atienza D., Fuentes VL., Olariaga A., Tilves U., Colahan C., Gili J-M. 2012. Temperature effects on asexual reproduction rates of scyphozoan species from the northwest Mediterranean Sea. Hydrobiologia 690:169-180.

Purcell JE., Uye S., Lo W-T. 2007. Anthropogenic causes of jellyfish blooms and their direct consequences for humans: a review. Marine Ecology Progress Series 350:153-174. DOI: 10.3354/meps07093.

Purcell JE., White JR., Nemazie DA., Wright DA. 1999. Temperature, salinity and food effects on asexual reproduction and abundance of the scyphozoan Chrysaora quinquecirrha. Marine Ecology Progress Series 180:187-196. DOI: 10.3354/meps180187.

Raposo A., Coimbra A., Amaral L., Gonçalves A., Morais Z. 2018. Eating jellyfish: safety, chemical and sensory properties. Journal of the Science of Food and Agriculture 98:39733981. DOI: 10.1002/jsfa.8921.

Rippingale RJ., Kelly SJ. 1995. Reproduction and survival of Phyllorhiza punctata (Cnidaria: Rhizostomeae) in a seasonally fluctuating salinity regime in Western Australia. Marine and Freshwater Research 46:1145-1151. DOI: http://dx.doi.org/10.1071/MF9951145.

Rodrigues M., Rosa A., Cravo A., Fortunato A., Jacob J. 2017. sCharacterisation of the study areas : Tagus estuary and Ria Formosa.

Rottini Sandrini L., Avian M. 1983. Biological cycle of Pelagia noctiluca: morphological aspects of the development from planula to ephyra. Marine Biology 74: 169-174.

Russell FS. 1970. The medusae of the British Iles II: Pelagic Scyphozoa with a supplement to the first volume on Hydromedusae. Cambridge Univ. Press.

Sanz-Martín M., Pitt KA., Condon RH., Lucas CH., Novaes de Santana C., Duarte CM. 2016. Flawed citation practices facilitate the unsubstantiated perception of a global trend toward increased jellyfish blooms. Global Ecology and Biogeography 25:1039-1049. DOI: $10.1111 /$ geb.12474. 
567 Schiariti A., Morandini AC., Jarms G., Von Glehn Paes R., Franke S., Mianzan H. 2014.

568

569

570

571

572

573

574

575

576

577

578

579

580

581

582

583

584

585

586

587

588

589

590

591

592

593

594

595

596

597

598

599

600

601

Asexual reproduction strategies and blooming potential in Scyphozoa. Marine Ecology

Progress Series 510:241-253. DOI: 10.3354/meps10798.

Straehler-Pohl I. 2009. Die Phylogenie der Rhopaliophora (Scyphozoa und Cubozoa) und die Paraphylie der' Rhizostomeae' Dissertation I. Universiät Hamburg.

Straehler-Pohl I., Jarms G. 2010. Identification key for young ephyrae: a first step for early detection of jellyfish blooms. Hydrobiologia 645:3-21. DOI: 10.1007/s10750-010-0226-7.

Straehler-Pohl I., Widmer CL., Morandini AC. 2011. sCharacterisations of juvenile stages of some semaeostome Scyphozoa (Cnidaria), with recognition of a new family (Phacellophoridae). Zootaxa 37:1-37.

Takao M., Uye S. 2018. Effects of low salinity on the physiological ecology of planulae and polyps of scyphozoans in the East Asian Marginal Seas: potential impacts of monsoon rainfall on medusa population size. Hydrobiologia. 815: 165-176. DOI: 10.1007/s10750018-3558-3.

Thein H., Ikeda H., Uye S ichi. 2012. The potential role of podocysts in perpetuation of the common jellyfish Aurelia aurita s.l. (Cnidaria: Scyphozoa) in anthropogenically perturbed coastal waters. Hydrobiologia 690:157-167. DOI: 10.1007/s10750-012-1045-9.

Tronolone VB., Morandini AC., Migotto AE. 2002. On the occurrence of Scyphozoan ephyrae (Cnidaria, Scyphozoa, Semaeostomeae and Rhixostomeae) in the Southeastern Brazilian Coast. Biota Neotropica 2:1-18. DOI: 10.1590/S1676-06032002000200008.

Wang B., Qin Y., Dong J., Li Y., Wang W., Li Y., Sun M., Liu C. 2013. Dynamic distribution of Nemopilema nomurai in inshore waters of the northern Liaodong Bay, Bohai Sea. Shengtai Xuebao/ Acta Ecologica Sinica 33:1701-1712. (Abstract in English). DOI: $10.5846 /$ stxb201112081878.

Wang Y-T., Zheng S., Sun S., Zhang F. 2015. Effect of temperature and food type on asexual reproduction in Aurelia sp. 1 polyps. Hydrobiologia 754:169-178. DOI: 10.1007/s10750014-2020-4.

Webster CN., Lucas CH. 2012. The effects of food and temperature on settlement of Aurelia aurita planula larvae and subsequent somatic growth. Journal of Experimental Marine Biology and Ecology 436-437:50-55. DOI: 10.1016/j.jembe.2012.08.014.

Widmer CL., Fox CJ., Brierley AS. 2016. Effects of temperature and salinity on four species of northeastern Atlantic scyphistomae (Cnidaria: Scyphozoa). Marine Ecology Progress Series 559:73-88. DOI: 10.3354/meps11879.

Xian W., Kang B., Liu R. 2005. Jellyfish blooms in the Yangtze estuary. Science 307:41. DOI: 10.1126/science.307.5706.41c.

Peer) reviewing PDF | (2021:05:61520:1:1:NEW 2 Aug 2021) 
602 Yongze X., Qian LIU., Mei Z., Yu Z., Tiezhu MI., Zhigang YU. 2016. Effects of temperature 603 and salinity on the asexual reproduction of Aurelia coerulea polyps. Journal of Oceanology 604 and Limnology.

605 Zhang F., Sun S., Jin X., Li C. 2012. Associations of large jellyfish distributions with 606 temperature and salinity in the Yellow Sea and East China Sea. Hydrobiologia 690:81-96. 607 DOI: $10.1007 / \mathrm{s} 10750-012-1057-5$.

608 Zuur AF., Ieno EN., Walker NJ., Saveliev A a., Smith GM. 2009. Mixed Effects Models and 609 Extensions in Ecology with R. Springer. DOI: 10.1017/CBO9781107415324.004.

610

611

612

613

614

615

616

617

618

619

620

621 


\section{Table $\mathbf{1}$ (on next page)}

Body proportions of $C$. tagi. scyphistoma and ephyra 


\begin{tabular}{lr}
\hline \multicolumn{2}{c}{ Scyphistoma } \\
\hline TBL & $1438 \pm 240 \mu \mathrm{m}$ \\
StL & $307 \pm 147 \mu \mathrm{m}$ \\
CL & $1131 \pm 190 \mu \mathrm{m}$ \\
HL & $321 \pm 67 \mu \mathrm{m}$ \\
MDD & $637 \pm 120 \mu \mathrm{m}$ \\
StL \% TBL & $21 \%$ \\
CL \% TBL & $79 \%$ \\
HL \% TBL & $23 \%$ \\
MDD \% CL & $57 \%$ \\
\hline & \\
\hline TBD & $2514 \pm 426 \mu \mathrm{m}$ \\
CDD & $968 \pm 166 \mu \mathrm{m}$ \\
TMLL & $822 \pm 143 \mu \mathrm{m}$ \\
RLL & $415 \pm 79 \mu \mathrm{m}$ \\
LStL & $418 \pm 105 \mu \mathrm{m}$ \\
CDD\%TBD & $39 \%$ \\
TMLL\%TBD & $33 \%$ \\
RLL\%TBD & $17 \%$ \\
RLL\%TMLL & $51 \%$ \\
LStL\%TMLL & $51 \%$ \\
TMLL\%CDD & $119 \%$ \\
\hline
\end{tabular}




\section{Table 2 (on next page)}

Statistical results on the effects of temperature, salinity and diet on $C$. tagi different life stages (ZlqP $=$ Zero-inflated quasi-Poisson model) 


\begin{tabular}{|c|c|c|c|c|c|c|c|c|c|c|}
\hline Variable tested & $\begin{array}{l}\text { Planktonic duration } \\
\text { (ANOVA) }\end{array}$ & $\begin{array}{l}\text { Podocyst } \\
\text { (ANOVA) }\end{array}$ & $\begin{array}{l}\text { Bet-str } \\
\text { (Wilcox) }\end{array}$ & $\begin{array}{l}\text { Str } \\
(t \text {-test })\end{array}$ & $\begin{array}{l}\text { Ephyra } \\
(t \text {-test })\end{array}$ & $\begin{array}{l}\text { Pre-str } \\
\text { (ZIqP) }\end{array}$ & Estimate & Std. Error & $\mathrm{z}$ value & $p$ value \\
\hline \multirow[t]{2}{*}{ Temperature } & $F(2,18)=25.8$ & $F(1,18)=1.62$ & - & - & - & Count model & & & & \\
\hline & $p<0.001$ & $p=0.21$ & & & & Intercept & 6.17 & 0.47 & 12.99 & $<0.001$ \\
\hline \multirow[t]{2}{*}{ Salinity } & $F(3,18)=4.1$ & - & - & - & - & Temperature & -0.16 & 0.03 & -5.37 & $<0.001$ \\
\hline & $p<0.01$ & & & & & Feed & -0.33 & 0.15 & -2.19 & 0.03 \\
\hline \multirow[t]{2}{*}{ Feed } & - & $F(2,18)=1.23$ & $p=0.8$ & $p<0.01$ & $p=0.7$ & & & & & \\
\hline & & $p=0.3$ & & & & Zero-inflated model & & & & \\
\hline \multirow[t]{2}{*}{$\begin{array}{l}\text { Temperature X } \\
\text { salinity }\end{array}$} & $F(6,18)=1.21$ & - & - & - & - & Intercept & 11.79 & 2.49 & 4.74 & $<0.001$ \\
\hline & $p=0.3 .1$ & & & & & Temperature & -0.51 & 0.12 & -4.15 & $<0.001$ \\
\hline \multirow[t]{2}{*}{$\begin{array}{l}\text { Temperature X } \\
\text { feed }\end{array}$} & - & $F(1,18)=1.89$ & - & - & - & Feed & -1.37 & 0.37 & -3.71 & $<0.001$ \\
\hline & & $p=0.17$ & & & & & & & & \\
\hline
\end{tabular}

2 


\section{Table 3 (on next page)}

Catostylus tagi ephyrae production and Pre-str, bet-str and str duration in day ( \pm SD) for each of the treatment groups. (n): number of scyphistoma 


\begin{tabular}{|c|c|c|c|c|c|c|}
\hline & \multicolumn{3}{|c|}{$15^{\circ} \mathrm{C}$} & \multicolumn{3}{|c|}{$20^{\circ} \mathrm{C}$} \\
\hline & Unfed & Rotifers & Artemia & Unfed & Rotifers & Artemia \\
\hline Ephyra . strobilation ${ }^{-1}$ & - & - & - & - & $6.3 \pm 3.4(13)$ & $6.9 \pm 3.6(9)$ \\
\hline \multicolumn{7}{|c|}{ Strobilation timing (day) } \\
\hline Pre-strobilation & - & $32.2 \pm 3(5)$ & - & - & $10.6 \pm 5.4(14)$ & $15 \pm 6.6(11)$ \\
\hline Bet-strobilation & - & - & - & - & $5.7 \pm 1.3(13)$ & $5.6 \pm 2.2(10)$ \\
\hline Strobilation & - & - & - & - & $2.5 \pm 2.5(13)$ & $6.4 \pm 3.7(10)$ \\
\hline
\end{tabular}

1 


\section{Table 4 (on next page)}

Polyp and ephyra morphology of Rhizostomida species. rc: rhopalial canal, vc: velar canal, *: brooding species.

Source: 1: Pitt (2000); 2: Straehler-pohl (2009); 3: Straehler-Pohl and Jarms (2010); 4:

Kienberger et al. (2018); 5: Fuentes et al. (2011); 6: Purcell et al. (2012); 7: Schiariti et al. (2014); 8: Holst et al. (2007), 9: Holst and Jarms (2007); 10: You et al. (2007); 11: Lotan et al. (1992); 12: Cargo (1971); 13: Calder (1973); 14: Schiariti et al. (2008); 15: Kawahara et al. (2006); 16: Calder (1982); 17: Sugiura (1966); 18: Kikinger (1992); 19: Prieto et al. (2010); 20: Sugiura (1963); 21: Sugiura (1964); 22: Sugiura (1965); 23: Rippingale and Kelly (1995); 24: Gohar and Eisawy (1960a); 25: Gohar and Eisawy (1960b); 26: Bigelow (1900) 
1 Table 4: Polyp and ephyra morphology of Rhizostomida species. $r c$ : rhopalial canal, $v c$ : velar canal, *: brooding species. Source: 1 : Pitt 2 (2000); 2: Straehler-pohl (2009); 3: Straehler-Pohl and Jarms (2010); 4: Kienberger et al. (2018); 5: Fuentes et al. (2011); 6: Purcell et 3 al. (2012); 7: Schiariti et al. (2014); 8: Holst et al. (2007), 9: Holst and Jarms (2007); 10: You et al. (2007); 11: Lotan et al. (1992); 12: 4 Cargo (1971); 13: Calder (1973); 14: Schiariti et al. (2008); 15: Kawahara et al. (2006); 16: Calder (1982); 17: Sugiura (1966); 18: 5 Kikinger (1992); 19: Prieto et al. (2010); 20: Sugiura (1963); 21: Sugiura (1964); 22: Sugiura (1965); 23: Rippingale and Kelly (1995); 6 24: Gohar and Eisawy (1960a); 25: Gohar and Eisawy (1960b); 26: Bigelow (1900)

\begin{tabular}{|c|c|c|c|c|c|c|c|c|c|c|c|c|}
\hline \multirow[t]{2}{*}{ Species } & \multicolumn{5}{|l|}{ Polyp } & \multicolumn{6}{|l|}{ Ephyrae } & \multirow[t]{2}{*}{ Source } \\
\hline & $\begin{array}{l}\text { Polyp } \\
\text { size } \\
\text { range } \\
(\mathrm{mm})\end{array}$ & $\begin{array}{l}\text { MDD } \\
(\mathrm{mm})\end{array}$ & $\begin{array}{l}\mathrm{Nb} \text {. of } \\
\text { tentacles }\end{array}$ & $\begin{array}{l}\text { Scyphistome, } \\
\text { hypostome }\end{array}$ & $\begin{array}{l}\text { Asexual } \\
\text { reproduction }\end{array}$ & $\begin{array}{l}\text { Strobilation } \\
\text { (ephyrae per } \\
\text { strobilation } \\
\text { /strobilation type) }\end{array}$ & $\begin{array}{l}\text { Ephyrae } \\
\text { size after } \\
\text { release } \\
(\mathrm{mm})\end{array}$ & $\begin{array}{l}\mathrm{Nb} \text {. of } \\
\text { marginal } \\
\text { lappets }\end{array}$ & $\begin{array}{l}\text { Shape of } \\
\text { rhopalial lappet }\end{array}$ & $\begin{array}{l}\text { Shape of velar } \\
\text { canal / rhopalial } \\
\text { canal }\end{array}$ & $\begin{array}{l}\text { Ephyra } \\
\text { colour }\end{array}$ & \\
\hline $\begin{array}{l}\text { Catostylus } \\
\text { tagi }\end{array}$ & $\begin{array}{l}1.08- \\
1.83\end{array}$ & $0.44-0.86$ & 16 & $\begin{array}{l}\text { Long, club- } \\
\text { shaped }\end{array}$ & Podocysts & $\begin{array}{l}\text { 1, monodisk (rare) } \\
\text { Up to } 15, \text { polydisk }\end{array}$ & $1.5-3.1$ & 8 & $\begin{array}{l}\text { Antler palm- } \\
\text { like, with } 2 \text { to } 7 \\
\text { finger-like } \\
\text { appendages }\end{array}$ & $\begin{array}{l}\text { Rhombical/ } \\
\text { slightly forked, } \\
\text { rounded points }\end{array}$ & $\begin{array}{l}\text { Dark pink to } \\
\text { dark red, red } \\
\text { statocysts }\end{array}$ & $\begin{array}{l}\text { Present } \\
\text { study }\end{array}$ \\
\hline $\begin{array}{l}\text { Catostylus } \\
\text { mosaicus* }\end{array}$ & $1.57-1.90$ & $0.69-0.81$ & $12-20$ & $\begin{array}{l}\text { Long, club- } \\
\text { shaped }\end{array}$ & $\begin{array}{l}\text { Lateral polyp buds, } \\
\text { podocysts, } \\
\text { pedalocysts, } \\
\text { longitudinal fission }\end{array}$ & $\begin{array}{l}1, \text { monodisk } \\
2-5, \text { polydisk }\end{array}$ & $1.9-2.26$ & 8 & $\begin{array}{l}\text { Antler palm- } \\
\text { like, with } 3 \text { to } 5 \\
\text { finger-like } \\
\text { appendages }\end{array}$ & $\begin{array}{l}\text { Spade-like } v c / \\
\text { slightly forked } \\
r c\end{array}$ & na & $1,2,3$ \\
\hline $\begin{array}{l}\text { Rhizotoma } \\
\text { luteun* }\end{array}$ & $1.34-2.5$ & 1.02 & $14-16$ & $\begin{array}{l}\text { Conspicuous } \\
\text { and flexible in } \\
\text { all stage }\end{array}$ & Podocysts & 1, monodisk & $3.41-4.52$ & $\begin{array}{l}\text { Typical } 8, \\
11\end{array}$ & $\begin{array}{l}\text { Bread knife } \\
\text { shaped }\end{array}$ & $\begin{array}{l}\text { Rhombical } v c \text { / } \\
\text { slightly forked } \\
r c\end{array}$ & $\begin{array}{l}\text { Light yellow } \\
\text { to light } \\
\text { brown }\end{array}$ & 4 \\
\hline $\begin{array}{l}\text { Rhizostoma } \\
\text { pulmo }\end{array}$ & $0.96-2.15$ & $0.53-1.16$ & $14-16$ & $\begin{array}{l}\text { Long, club- } \\
\text { shape and } \\
\text { flexible }\end{array}$ & $\begin{array}{l}\text { Lateral polyp buds, } \\
\text { podocysts, lateral } \\
\text { buds, } \\
\text { stolonial polyp } \\
\text { buds, pedalocysts }\end{array}$ & $\begin{array}{l}\text { 8-13.5, polydisk, } \\
\text { oligodisk }\end{array}$ & $2.28-3.93$ & $\begin{array}{l}\text { Typical 8, } \\
5-9\end{array}$ & $\begin{array}{l}\text { Spade like to } \\
\text { lancet shaped }\end{array}$ & $\begin{array}{l}\text { Rhombical or } \\
\text { absent } v c / \\
\text { slightly forked } \\
r c\end{array}$ & $\begin{array}{l}\text { Milk } \\
\text { transparent to } \\
\text { opaque white }\end{array}$ & $\begin{array}{l}2,3,5, \\
6,7\end{array}$ \\
\hline $\begin{array}{l}\text { Rhizostoma } \\
\text { octopus }\end{array}$ & $1.9-2.3$ & 1.25 & $16-24$ & $\begin{array}{l}\text { Long and } \\
\text { flexible }\end{array}$ & $\begin{array}{l}\text { Podocysts, lateral } \\
\text { buds, longitudinal } \\
\text { fission }\end{array}$ & $\begin{array}{l}1, \text { monodisk } \\
\text { Up to } 15 \text {, polydisk }\end{array}$ & $27-5.96$ & 8 & Bread knife-like & $\begin{array}{l}\text { flat rhombical } \\
v c \text { / slightly } \\
\text { forked } r c\end{array}$ & $\begin{array}{l}\text { Milky } \\
\text { transparent, } \\
\text { light yellow } \\
\text { to light } \\
\text { brown }\end{array}$ & $2,8,9$ \\
\hline
\end{tabular}




\section{Table 4 continued}

\begin{tabular}{|c|c|c|c|c|c|c|c|c|c|c|c|c|}
\hline \multirow[t]{2}{*}{ Species } & \multicolumn{5}{|l|}{ Polyp } & \multicolumn{6}{|l|}{ Ephyrae } & \multirow[t]{2}{*}{ Source } \\
\hline & $\begin{array}{l}\text { Polyp size } \\
\text { range } \\
(\mathrm{mm})\end{array}$ & $\begin{array}{l}\text { MDD } \\
(\mathrm{mm})\end{array}$ & $\begin{array}{l}\text { Nb. of } \\
\text { tentacles }\end{array}$ & $\begin{array}{l}\text { Scyphistome } \\
\text { hypostome }\end{array}$ & $\begin{array}{l}\text { Asexual } \\
\text { reproduction }\end{array}$ & $\begin{array}{l}\text { Strobilation } \\
\text { (ephyrae per } \\
\text { strobilation } \\
\text { /strobilation type) }\end{array}$ & $\begin{array}{l}\text { Ephyrae } \\
\text { size after } \\
\text { release } \\
(\mathrm{mm})\end{array}$ & $\begin{array}{l}\text { Nb. of } \\
\text { marginal } \\
\text { lappets }\end{array}$ & $\begin{array}{l}\text { Shape of } \\
\text { rhopalial lappet }\end{array}$ & $\begin{array}{l}\text { Shape of velar } \\
\text { canal / rhopalial } \\
\text { canal }\end{array}$ & $\begin{array}{l}\text { Ephyra } \\
\text { colour }\end{array}$ & \\
\hline $\begin{array}{l}\text { Rhopilema } \\
\text { esculentum }\end{array}$ & $1.00-3.50$ & 1.6 & 16 & Moderately long & Podocysts & 7-17, polydisk & $1.5-4.0$ & 8 & $\begin{array}{l}\text { Talon-shaped } \\
\text { with 4-6 } \\
\text { branches ; Hand } \\
\text { saped with 4-6 } \\
\text { finger-like } \\
\text { appendages }\end{array}$ & $\begin{array}{l}\text { arrow tip-like } v c \\
\text { / spatula-like } r c\end{array}$ & $\begin{array}{l}\text { Milky to } \\
\text { transparent }\end{array}$ & $2,3,10$ \\
\hline $\begin{array}{l}\text { Rhopilema } \\
\text { nomadica }\end{array}$ & $1.8-2.0$ & na & 16 & $\begin{array}{l}\text { Large clavate } \\
\text { shape, third of } \\
\text { polyp length }\end{array}$ & Podocysts & 5-6, polydisk & $1.5-2.0$ & 8 & $\begin{array}{l}\text { Single or twin- } \\
\text { typed, lancet- } \\
\text { shaped }\end{array}$ & $\begin{array}{l}\text { Convex with } \\
\text { arched corners }\end{array}$ & na & 11 \\
\hline $\begin{array}{l}\text { Rhopilema } \\
\text { verrilli* }\end{array}$ & 2.5 & 0.35 & 8- 20 & $\begin{array}{l}\text { Large, flexible, } \\
\text { quadrate, } \\
\text { irregular in } \\
\text { outline }\end{array}$ & $\begin{array}{l}\text { Podocysts, } \\
\text { pedalocysts }\end{array}$ & $\begin{array}{l}\text { 1, monodisk } \\
\text { Up to } 3 \text {, polydisk }\end{array}$ & 3.0 & 8 & $\begin{array}{l}\text { Rounded, } \\
\text { slender, pointed } \\
\text { distally }\end{array}$ & $\begin{array}{l}\text { Rhopalar } \\
\text { pouches with } \\
\text { prominent } \\
\text { «horns» }\end{array}$ & $\begin{array}{l}\text { Peach, } \\
\text { orange-red to } \\
\text { rose coloured } \\
\text { birefringent, } \\
\text { bright yellow } \\
\text { gold statocysts }\end{array}$ & 12,13 \\
\hline $\begin{array}{l}\text { Lychnorhiza } \\
\text { lucerna }\end{array}$ & 1.5 & $\begin{array}{l}0.55- \\
0.8\end{array}$ & $18-22$ & $\begin{array}{l}\text { Prominent dome- } \\
\text { shaped }\end{array}$ & Podocysts & 3 , polydisk & 1.4 & 8 & $\begin{array}{l}\text { Hand shaped } \\
\text { with } 2 \text { to } 9 \text { tips }\end{array}$ & $\begin{array}{l}\text { na / } \\
\text { square-shaped } \\
\text { ends with slight } \\
\text { lateral horns } r c\end{array}$ & Translucent & 14 \\
\hline $\begin{array}{l}\text { Nemopilema } \\
\text { nomadica }\end{array}$ & 2.6 & $0.8-1.1$ & 16 & $\begin{array}{l}\text { Dome-shaped, } \\
\text { one third of } \\
\text { scyphistome } \\
\text { height }\end{array}$ & Podocysts & 3-7, polydisk & $2.2-3.8$ & 8 & $\begin{array}{l}\text { Hand shaped } \\
\text { with } 2 \text { to } 6 \\
\text { pointed tips }\end{array}$ & $\begin{array}{l}\text { Unforked } \\
\text { triangular } v c / \\
\text { unforked, } \\
\text { spatula shaped } \\
r c\end{array}$ & Translucent & 15 \\
\hline $\begin{array}{l}\text { Stomolophus } \\
\text { meleagris }\end{array}$ & 2.0 & na & 16 & $\begin{array}{l}\text { Large, flexible, } \\
\text { and dome-or } \\
\text { knob-shaped }\end{array}$ & Podocysts & $\begin{array}{l}\text { 1, monodisk } \\
2-3 \text {, polydisk }\end{array}$ & $1.5-2.0$ & 8 & $\begin{array}{l}\text { Slender, distally } \\
\text { pointed }\end{array}$ & $\begin{array}{l}\text { Adradial bulges } \\
v c / \text { blunt- } \\
\text { ended } r c\end{array}$ & $\begin{array}{l}\text { Pale straw } \\
\text { coloured }\end{array}$ & 16 \\
\hline $\begin{array}{l}\text { Cephea } \\
\text { cephea* }\end{array}$ & $1.4-2.9$ & $\begin{array}{l}0.44- \\
0.6\end{array}$ & $14-17$ & $\begin{array}{l}\text { Short, } \\
\text { club-shaped }\end{array}$ & $\begin{array}{l}\text { Lateral } \\
\text { budding, } \\
\text { swimming } \\
\text { buds }\end{array}$ & 1, monodisk & $1.6-3.24$ & 8 & $\begin{array}{l}\text { Round spoon- } \\
\text { shaped }\end{array}$ & $\begin{array}{l}\text { Rhombical } v c / \\
\text { slightly forked } \\
r c\end{array}$ & $\begin{array}{l}\text { Pale yellow to } \\
\text { yellowish- } \\
\text { brown }\end{array}$ & $2,3,17$ \\
\hline
\end{tabular}


12 Table 4 continued

\begin{tabular}{|c|c|c|c|c|c|c|c|c|c|c|c|c|}
\hline \multirow[t]{2}{*}{ Species } & \multicolumn{5}{|l|}{ Polyp } & \multicolumn{6}{|l|}{ Ephyrae } & \multirow[t]{2}{*}{ Source } \\
\hline & $\begin{array}{l}\text { Polyp } \\
\text { size } \\
\text { range } \\
(\mathrm{mm})\end{array}$ & $\begin{array}{l}\text { MDD } \\
(\mathrm{mm})\end{array}$ & $\begin{array}{l}\text { Nb. of } \\
\text { tentacles }\end{array}$ & $\begin{array}{l}\text { Scyphistome, } \\
\text { hypostome }\end{array}$ & $\begin{array}{l}\text { Asexual } \\
\text { reproduction }\end{array}$ & $\begin{array}{l}\text { Strobilation } \\
\text { (ephyrae per } \\
\text { strobilation } \\
\text { /strobilation type) }\end{array}$ & $\begin{array}{l}\text { Ephyrae } \\
\text { size after } \\
\text { release } \\
(\mathrm{mm})\end{array}$ & $\begin{array}{l}\mathrm{Nb} \text {. of } \\
\text { marginal } \\
\text { lappets }\end{array}$ & $\begin{array}{l}\text { Shape of } \\
\text { rhopalial lappet }\end{array}$ & $\begin{array}{l}\text { Shape of velar } \\
\text { canal / rhopalial } \\
\text { canal }\end{array}$ & Ephyra colour & \\
\hline $\begin{array}{l}\text { Cotylorhiza } \\
\text { tuberculata* }\end{array}$ & $\begin{array}{l}3.23- \\
5.0\end{array}$ & $\begin{array}{l}0.82- \\
0.86\end{array}$ & $16-17$ & Short, cylindrical & $\begin{array}{l}\text { Lateral } \\
\text { budding, } \\
\text { swimming } \\
\text { buds }\end{array}$ & 1, monodisk & $1.5-3.25$ & 8 & $\begin{array}{l}\text { Rounded to } \\
\text { rounded spoon } \\
\text { shaped }\end{array}$ & $\begin{array}{l}\text { spade-like to } \\
\text { slightly } \\
\text { rhombical } v c / \\
\text { slightly forked } \\
r c\end{array}$ & $\begin{array}{l}\text { Transparent with } \\
\text { yellow hemmed } \\
\text { gastric system }\end{array}$ & $\begin{array}{r}2,3 \\
18 \\
, 19\end{array}$ \\
\hline $\begin{array}{l}\text { Mastigias } \\
\text { papua* }\end{array}$ & $\begin{array}{l}1.0- \\
10.22\end{array}$ & $\begin{array}{l}0.4- \\
0.92\end{array}$ & $15-18$ & $\begin{array}{l}\text { Very } \\
\text { short,cylindrical }\end{array}$ & Planuloids & 1 , monodisk & $1.5-3.91$ & 8 & $\begin{array}{l}\text { Rounded; } \\
\text { Trapered, broad } \\
\text { spoon shaped }\end{array}$ & $\begin{array}{l}\text { spade-like to } \\
\text { slightly } \\
\text { rhombical } v c / \\
\text { slightly forked } \\
r c\end{array}$ & $\begin{array}{l}\text { Brown to orange } \\
\text { brown }\end{array}$ & $\begin{array}{r}2,3, \\
20, \\
21,22\end{array}$ \\
\hline $\begin{array}{l}\text { Phyllorhiza } \\
\text { punctata* }\end{array}$ & na & na & 16 & na & Ciliated buds & 1 , monodisk & $0.46-2.5$ & 8 & $\begin{array}{l}\text { Pointed spoon } \\
\text { shaped }\end{array}$ & $\begin{array}{l}\text { spade-like to } \\
\text { slightly } \\
\text { rhombical } v c / \\
\text { slightly forked } \\
r c\end{array}$ & $\begin{array}{l}\text { Yellowish brown } \\
\text { to ochre }\end{array}$ & 3,23 \\
\hline $\begin{array}{l}\text { Cassiopea } \\
\text { andromeda* }\end{array}$ & $\begin{array}{l}4.72- \\
10.0\end{array}$ & 1.95 & 32 & $\begin{array}{l}\text { Conspicuous } \\
\text { long, tetragonal }\end{array}$ & $\begin{array}{l}\text { Swimming } \\
\text { buds, } \\
\text { planuloids }\end{array}$ & 1 , monodisk & $3.69-3.95$ & $12-23$ & Spatula-like & $\begin{array}{l}\text { tongue-like and } \\
\text { reach the tips of } \\
\text { the velar } \\
\text { lappets, tips are } \\
\text { rounded } v c / \\
\text { long forked } r c\end{array}$ & Yellowish green & $\begin{array}{r}2,3, \\
24,25\end{array}$ \\
\hline $\begin{array}{l}\text { Cassiopea } \\
\text { xamachana }\end{array}$ & na & $1.5-2.0$ & Up to 42 & na & $\begin{array}{l}\text { Planula-like } \\
\text { larvae }\end{array}$ & 1 , monodisk & na & na & na & na & na & 26 \\
\hline
\end{tabular}




\section{Figure 1}

Measuring points and measurements defined and taken in a polyp (A) and newly released ephyra (B).

TBL: total body length, CL: calyx length, HL: hypostome length, MDD: mouth disc diameter, StL: stalk length, TBD: total body diameter, CDD: central disc diameter, TMLL: total marginal lappet length, LStL: lappet stem length, RLL: rhopalial lappet length.
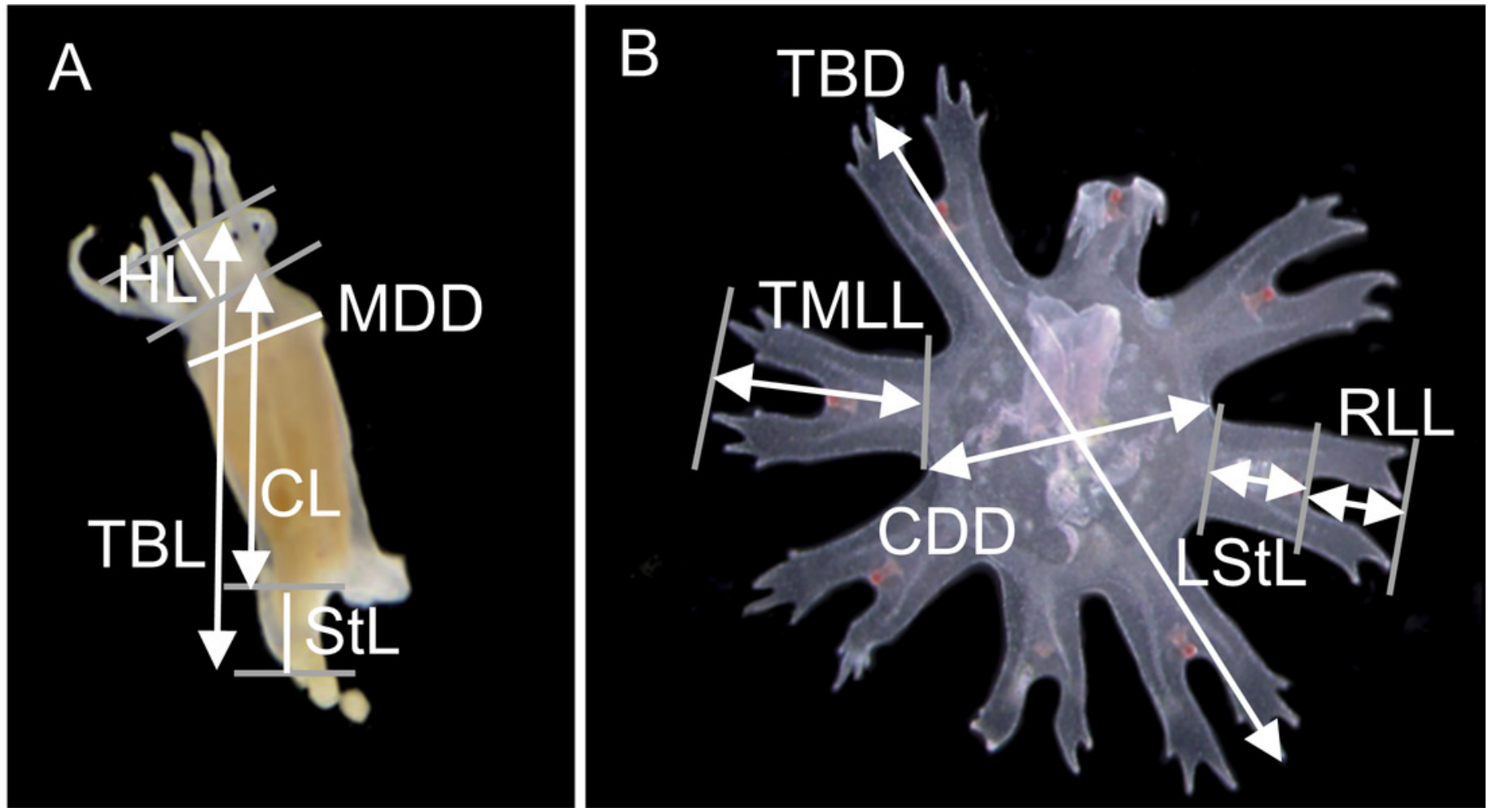


\section{Figure 2}

Catostylus tagi life cycle from scyphistoma (A-E) to metaephyra and development stages of gastric system (F-M).

ed: ephyrae disc; ep: ephyrae; lb: lappet bud; ma: manubrium; $m$ l: marginal lobe; $p d$ : podocyst; pr: primary ring canal; rc: rhopalial canal; rl: rhopalar lappet; rh: rhopalium; sr: secondary ring canal; vc: velar canal; vl: velar lappet. Scale bars: all $1 \mathrm{~mm}$ except F: 500 $\mu \mathrm{m}$.(Photo credit Sonia KM Gueroun).
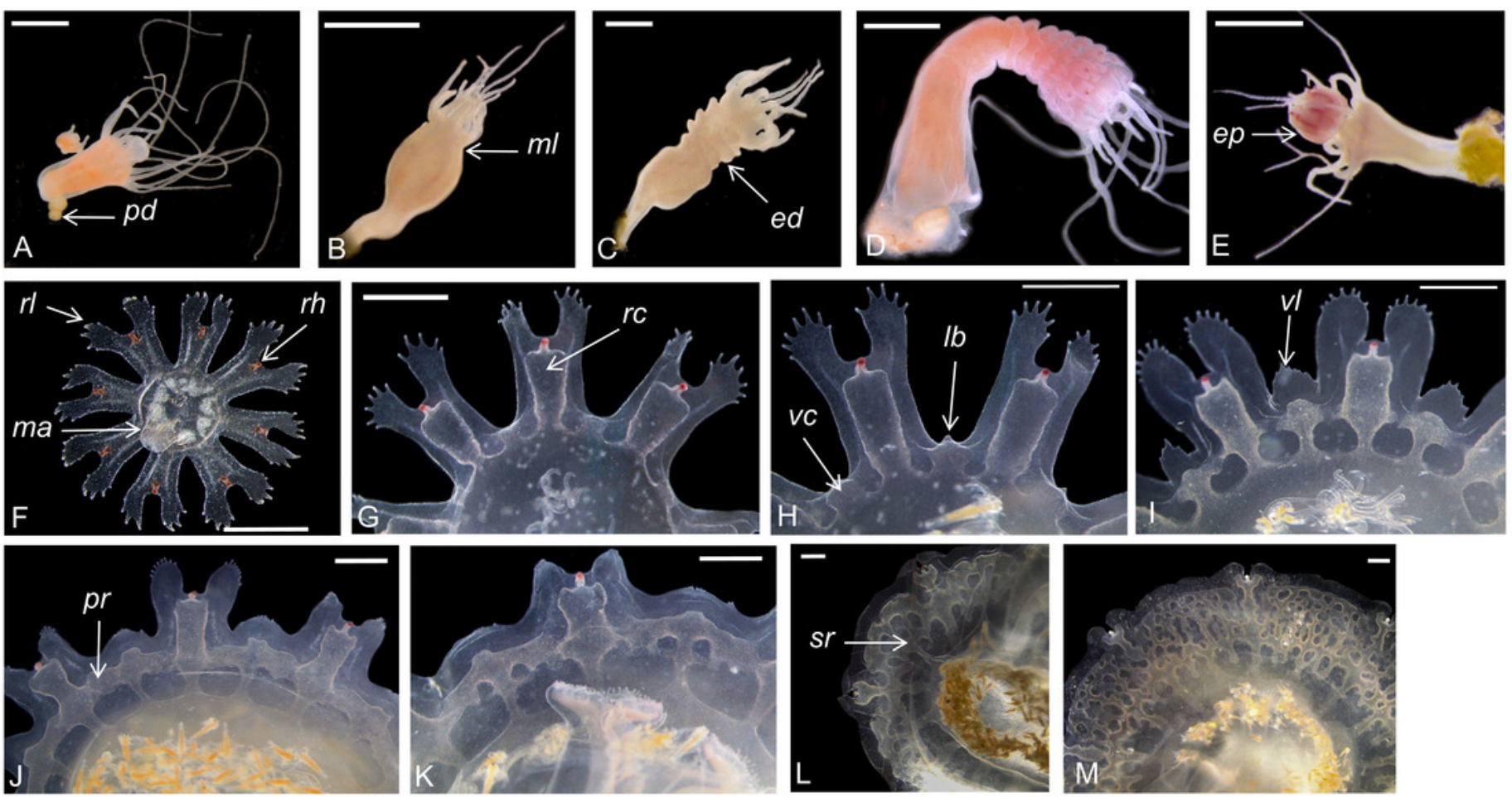
Figure 3

Enlarged view of the mouth development of Catostylus tagi.

A. Cross-shaped mouth without oral tentacles of a stage 0 ephyrae. B. Appearance of tiny oral tentacles at the lips mouth in stage 1. C. Oral lips distally divided to eight oral arms in stage 2. D two oral arms in stage 6. oa: oral arm; ot; oral tentacles. (Photo credit Sonia KM Gueroun). 

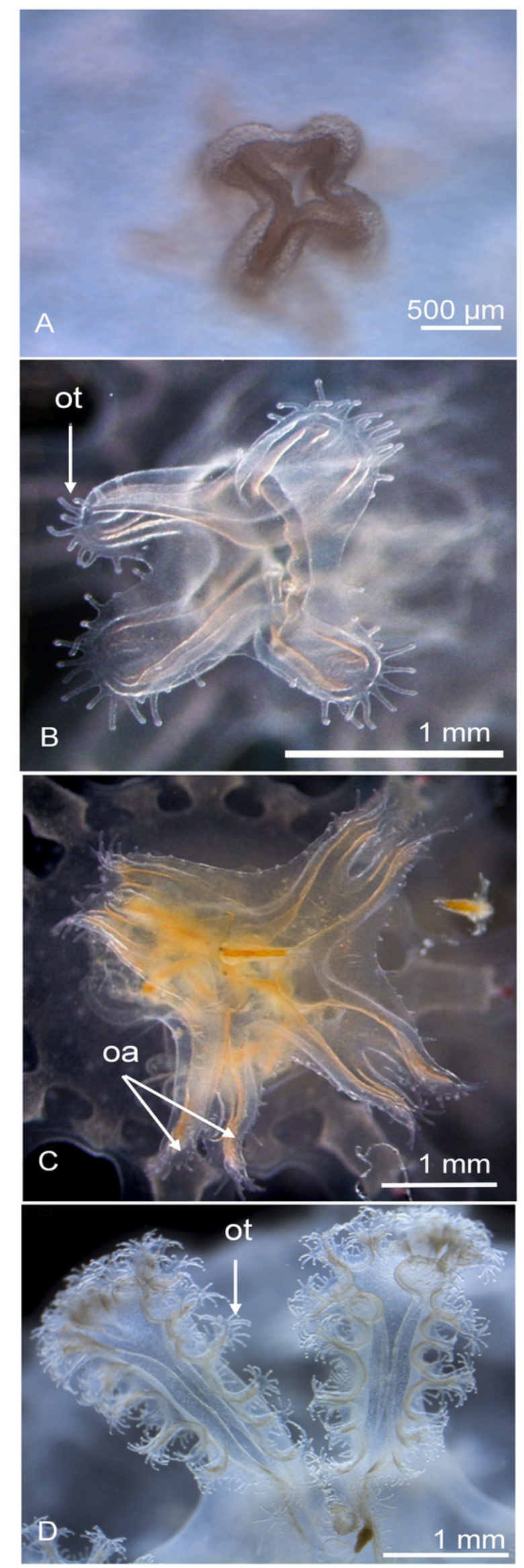

PeerJ reviewing PDF | (2021:05:61520:1:1:NEW 2 Aug 2021) 


\section{Figure 4}

Photography of a fully developed Catostylus tagi medusae reared in the Lisbon Oceanário (Photo credit Raul Gouveia).

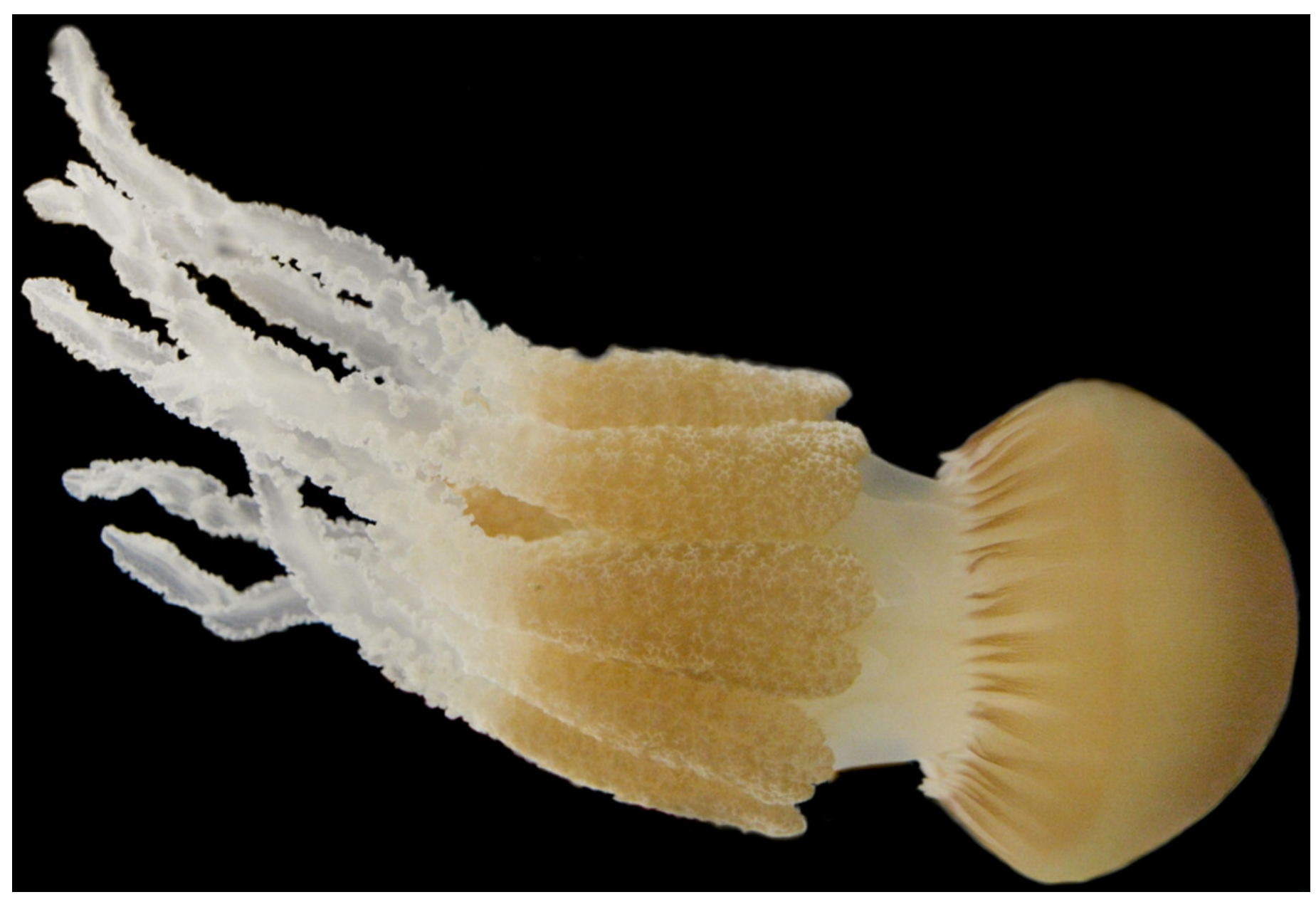


Figure 5

Catostylus tagi planula survival and development in different temperature and salinity regimes.

Stage 0: Settled; Stage 1: 1-4 tentacles; Stage 2: 5-7 tentacles; Stage 3: 8-16 tentacles. 

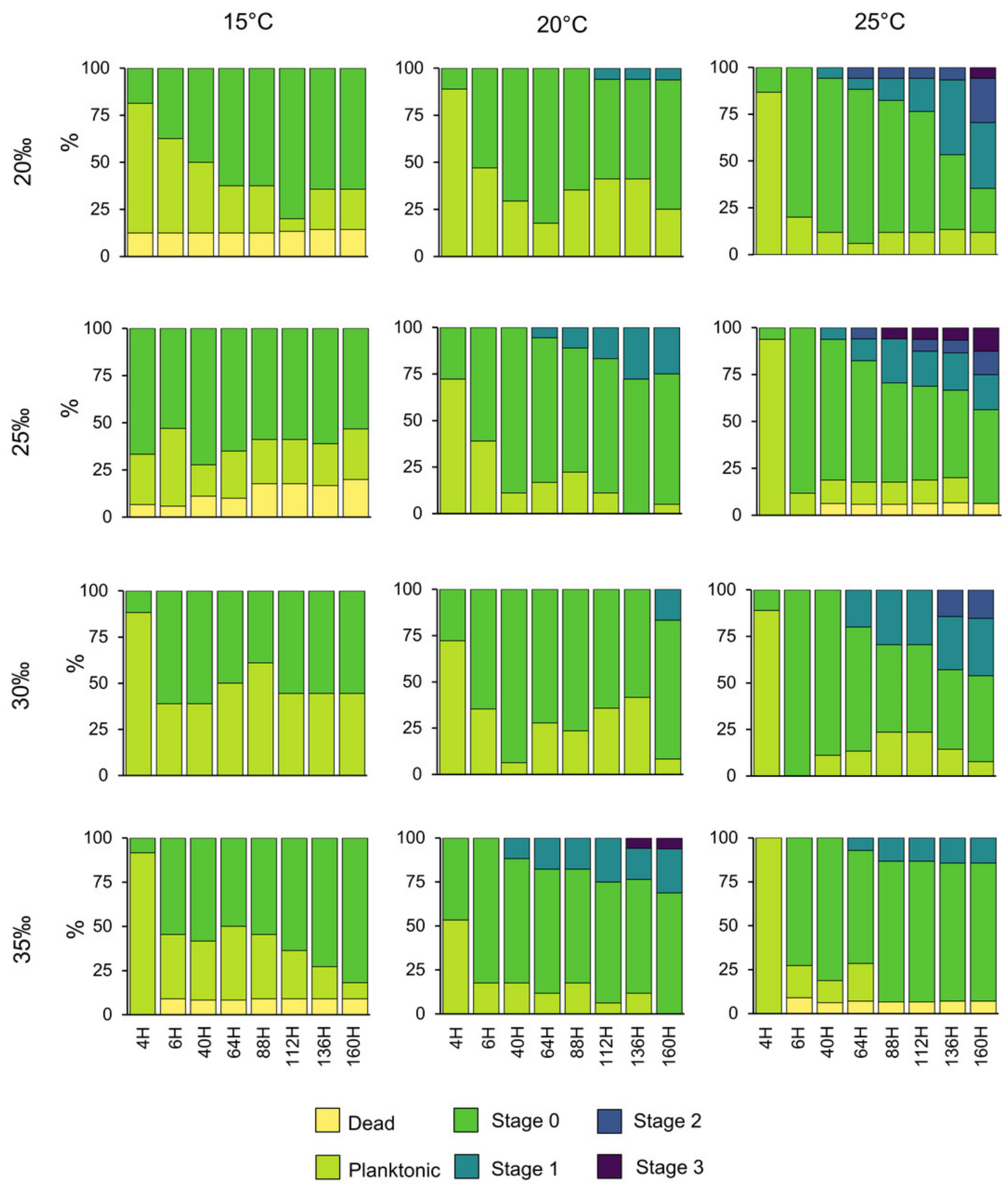
Figure 6

Average $( \pm \mathrm{SD}$ ) of the planktonic duration of Catostylus tagi planulae exposed to different temperature and salinity regimes

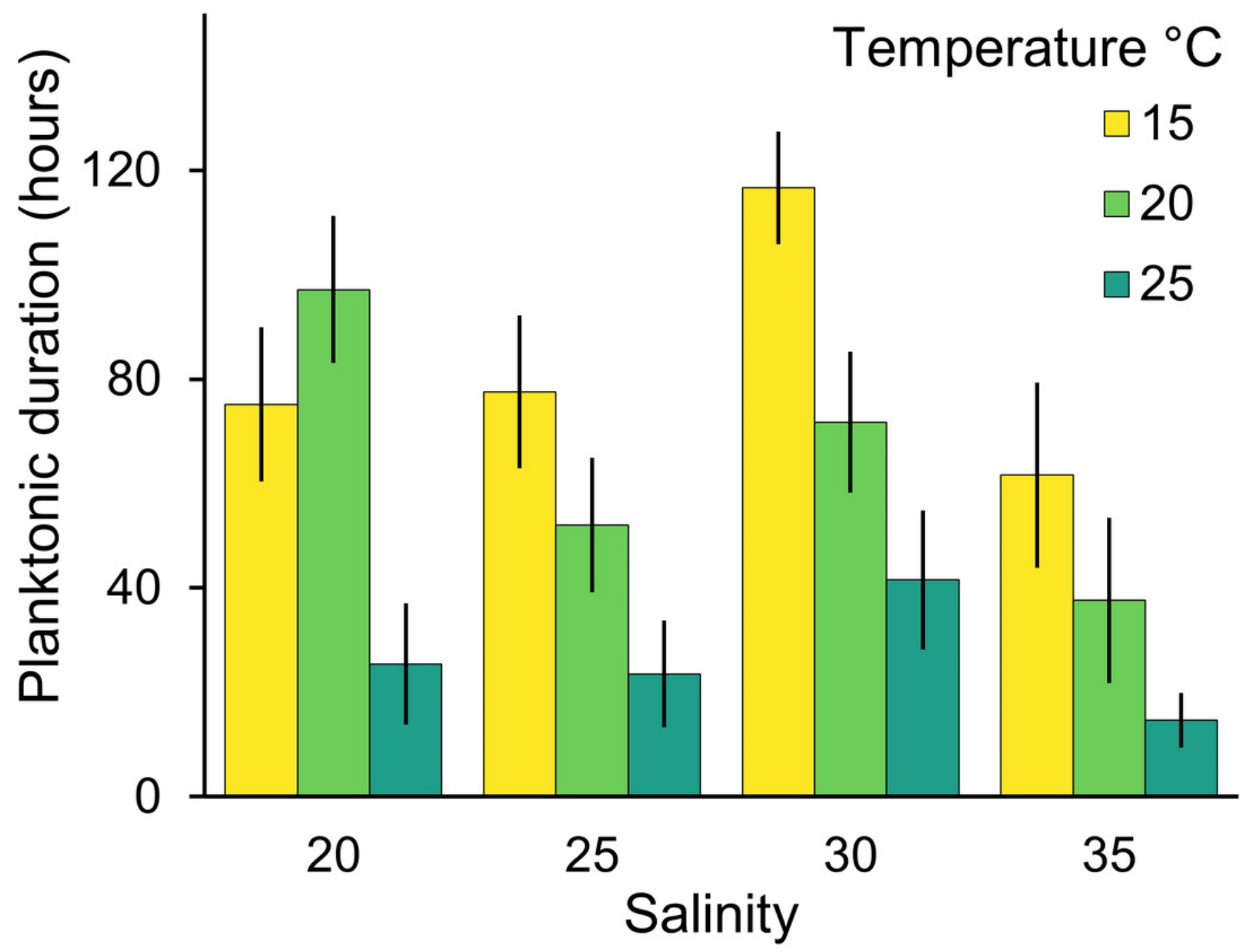


Figure 7

Catostylus tagi average $( \pm \mathrm{SD})$ podocyst production per scyphistoma under different temperature and diet regimes.

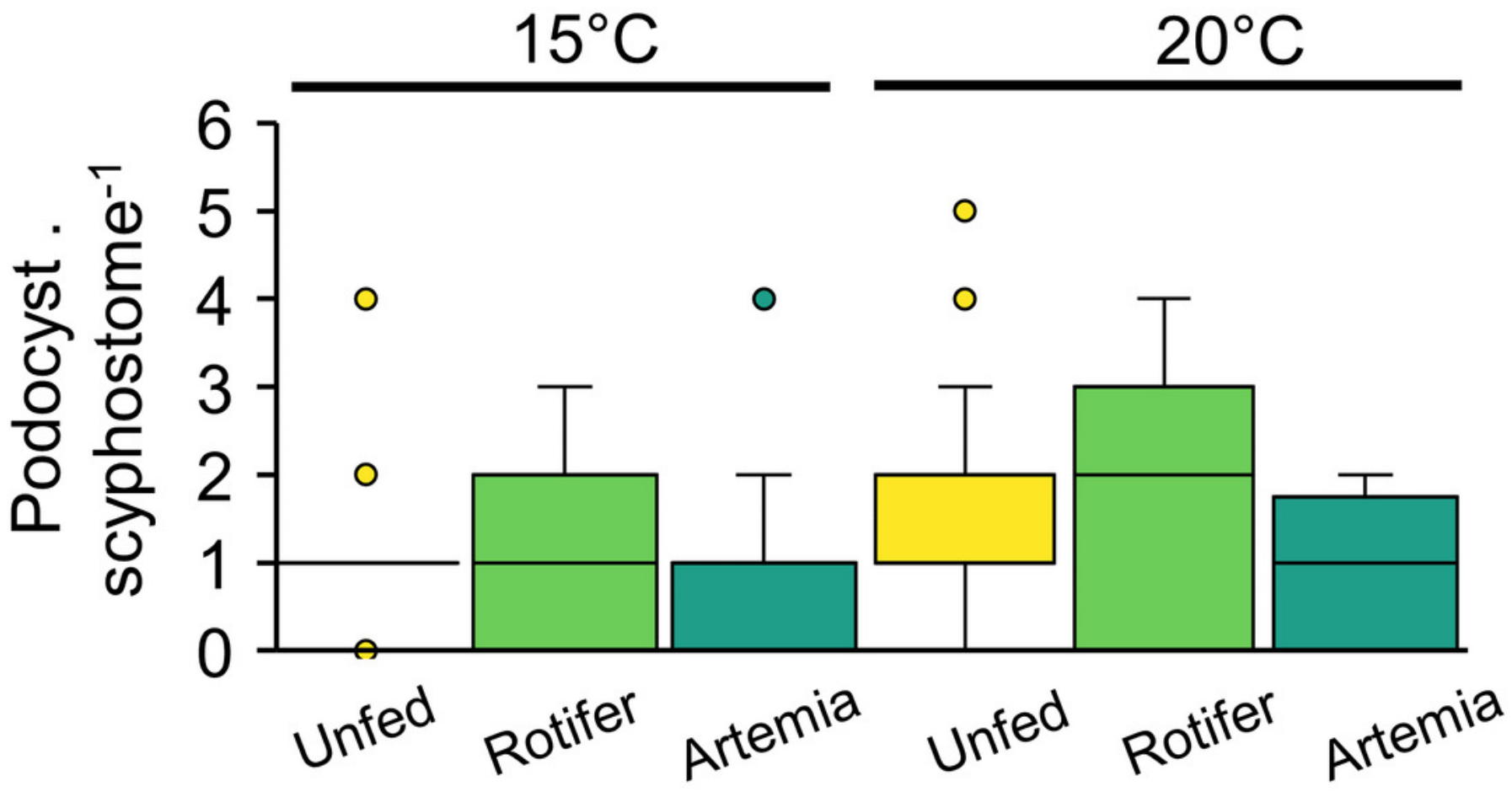


Figure 8

Spatial (A) and monthly (B) occurrence of Catostylus tagi medusa along the Tagus estuary in 2019
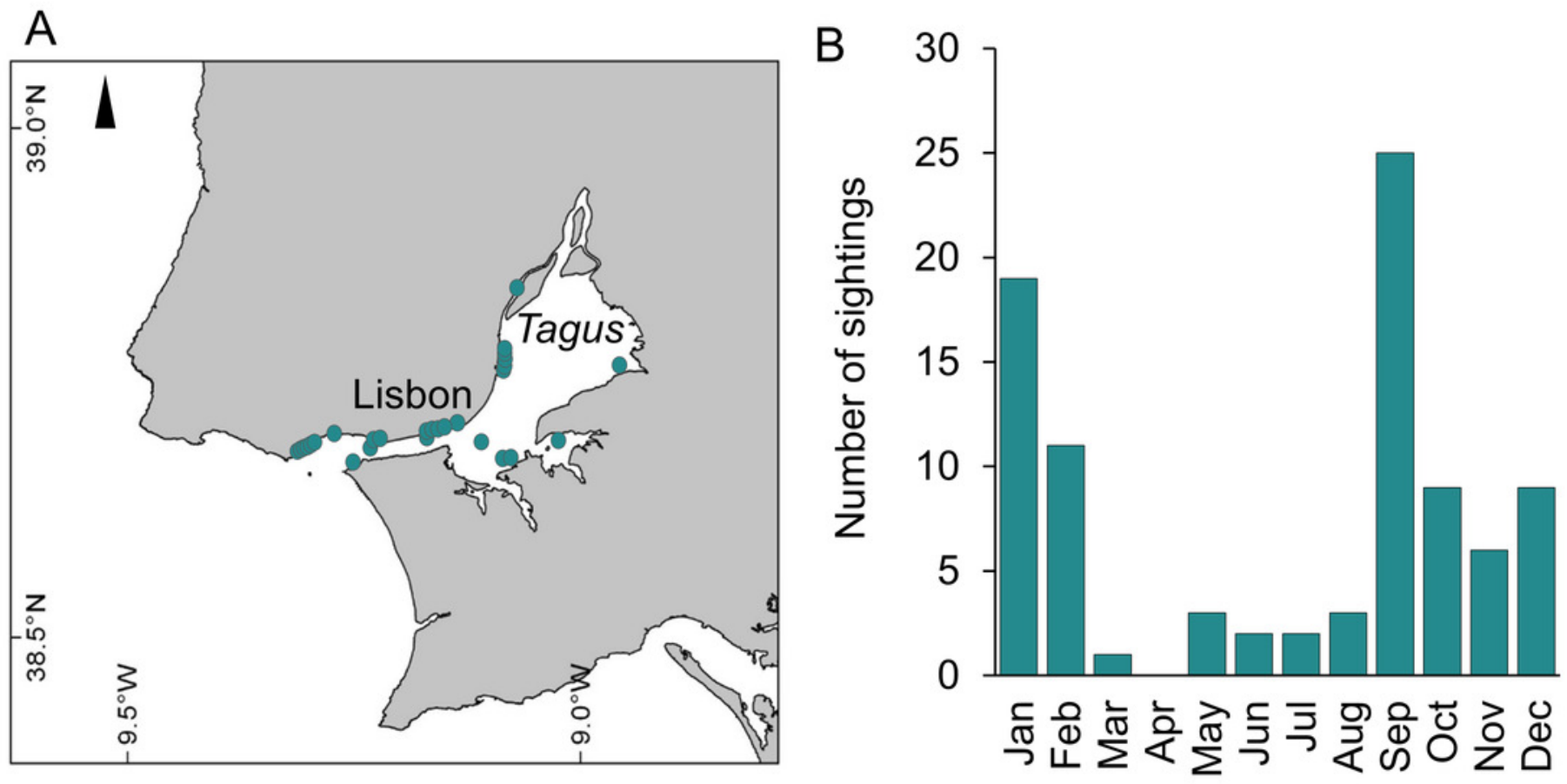